\title{
Sosyo-Kültürel Özellikler Bağlamında Erken Evlilikler: Ağrı Örneği
}

\section{Early Marriages in Terms of their Socio-Cultural Features: Sample from Ăgrt}

\author{
Meyrem TUNA UYSAL * \\ Gizem TAN EREN** \\ Esma Ş่̇MŞEK $^{* * *}$
}

Öz: Erken evlilik ya da çocuk evlilikler günümüzde sorun olarak tanımlanması gereken toplumsal bir olaydır. Ataerkil ve geleneksel toplum yapısına sahip toplumlarda erken evlilikler geleneğe dönüsstürülerek meşrulaştırılmaktadır. Buradan hareketle bu araştırma, erken evliliklerde sosyo-kültürel yapının etkisini ele almaktadır. Araştırmanın amacı, Ağrı ilinde erken evlilik yapmış kadın ve erkeklerin anlatılarından hareketle erken evliliğin gerçekleşmesinde içinde bulunulan toplumun sosyo-kültürel özelliklerinin etkisini ortaya koymaktır. Bu çerçevede çalışma Ağrı ilinde 8 kadın, 8 erkek olmak üzere toplam 16 katılımcı ile gerçekleştirilmiştir. Araştırmada nitel araştırma yöntemi ve derinlemesine görüşme tekniği kullanılmıştır. Görüşmeler, katılımcılarla yüz yüze gerçekleştirilmiştir. Araştırma gerçekleştirilirken literatürde, erken evlilik üzerine yapılan çalışmaların "kadın" temelli olduğu görülmüştür. Bu araştırmada ise erken evliliklerin hem "kadın" hem de "erkek"ler açısından ele alınması araştırmanın önemini arttırmaktadır. Diğer yandan araştırma, erken evlilikler açısından sosyo-kültürel yapının belirleyiciliğini göstermesi bakımından da önem taşımaktadır. Araştırma sonucunda erken evliliklerin sosyokültürel yapıda hakim olan ataerkillik, gelenek-görenekler, eğitimsizlik, ekonomik durumun düşük olmas1, dini inançlar gibi nedenlerle gerçekleştirildiği ve eğitimsizlik, çocuk istismarı, ebeveyn rollerinin benimsenememesi, geçimsizlik, şiddet, boşanma gibi sonuçlara neden olduğu görülmüştür.

\section{Anahtar sözcükler: Erken Evlilik, Çocuk Evlilik, Ataerkillik, Sosyo-Kültürel Yapı}

Abstract: Early marriage or child marriages is social phenomenon that should be defined as a problem today. In societies with patriarchal and traditional social structure, early marriages are legitimized by becoming traditions. Thus, this study deals with the impact of socio-cultural structure in early marriages. The aim of this study is to reveal the effects of socio-cultural characteristics of the society in early marriages, based on the narratives of women and men who had married early in Ağrı. In this context, the study was carried out with a total of 16 participants, 8 female and 8 male. Qualitative research method and in-depth interview technique were used in the study. The interviews were conducted face to face with the participants. It was observed that the studies in the literature on early marriage were based on women. In this study, handling early marriages in terms of both "women" and "men" increases importance of the research. On the other hand, research is important in terms of demonstrating the determinism of sociocultural structure in early marriages. As result of the research, it was seen that early marriages are carried out reasons such as patriarchy, traditions, lack of education, low economic status and religious beliefs, and they cause results like lack of education, child abuse, lack of parental roles, incompatibility, violence and divorce.

Keywords: Early Marriage, Child Marriage, Patriarchy, Socio-Cultural Structure

\footnotetext{
* Dr. Öğ. Ü., Süleyman Demirel Üniversitesi, Fen-Edebiyat Fakültesi, Sosyoloji Bölümü, Isparta. meyremtuna@sdu.edu.tr, https://orcid.org/0000-0001-8910-8058

** Arş. Gör., Süleyman Demirel Üniversitesi, Fen-Edebiyat Fakültesi, Sosyoloji Bölümü, Isparta. gizemeren@sdu.edu.tr, https://orcid.org/0000-0001-6669-8411

MA., Süleyman Demirel Üniversitesi, Sosyal Bilimler Enstitüsü, Sosyoloji Anabilim Dalı, Isparta. esma.simsek09@gmail.com, https://orcid.org/0000-0001-6194-4521
} 


\section{Giriş}

Erken evlilikler bugün dünyanın birçok yerinde karşılaşılan önemli bir toplumsal sorun olarak karşımıza çıkmaktadır. Toplumdan topluma, kültürden kültüre değişiklik gösterse de bu evliliklerin ortaya çıkmasında sosyo-kültürel, sosyo-ekonomik başta olmak üzere birden çok faktör etkili olmaktadır. Ancak erken evliliklerin yapıldığı ülkelerin özellikle sosyo-kültürel özellikleri ele alındığında benzer özellikler kendini göstermektedir. Bu toplumlardaki ataerkil ve geleneksel toplum yapısı erken yaşta evlilikleri normalleştirmekte, bunun toplum nezdinde meşruluk kazanmasına neden olmaktadır. Ataerkil ve geleneksel toplum, sahip olduğu kültürel değerler nedeniyle erken evliliği bir sorun olarak görmemekte, o toplumun değerleri olarak kabul etmekte ve bunu da "gelenek" adı altında değerlendirmektedir.

Türkiye açısından ele alındığında ise yine benzer özellikler kendini göstermektedir. Özellikle Doğu ve Güneydoğu Anadolu bölgelerinde erken yaşta evlilik; başlık parası, berdel, beşik kertmesi gibi uygulamalarla "adet" adı altında uygulanmakta, bu gibi uygulamalar normal kabul edilerek kız çocuklarının erken yaşta evlendirilmesine neden olmaktadır (Aydemir 2011, 18). Çocuklar çok küçük yaşlardan itibaren erken yaşta evlendirilmeye özendirilmektedir. Hatta erken yaşta evliliği kabul etmeyen çocuklar üzerinde "evde kalırsın", "bahtın kapanır" gibi ifadelerle bir baskı oluşturularak onların erken yaşta evlendirilmesi sağlanmaya çalışılmaktadır. Dolayısıyla erken evlilikler birçok olumsuz sonucu da beraberinde getirmektedir. Ataerkil aile yapısı çocuklarını erken yaşta evlendirerek onların eğitimlerinin yarıda kalmasına ve onların çocuk yaşta ev içi rolleri üstlenmesine, aile içerisinde ikincil konuma düşmelerine, çocuk yaşta anne olmalarına, yoksulluğa, şiddete maruz kalmalarına ve istismara uğramalarına neden olmaktadir.

Geleneksel toplumlarda hem kız hem de erkek çocuklarına kendi hayatları hakkında karar verme ve tercih yapma hakkı tanınmamaktadır. Hem erkek çocukları hem de kız çocukları evlenecekleri kişileri kendileri seçememekte, ailelerinin uygun gördüğü kişilerle evlenme durumunda kalmaktadır. Her ne kadar erken yaşta evlilik kız çocuklarındaki kadar yaygın olmasa da erkek çocuklarında da erken yaşta evlenme/evlendirilme durumları mevcuttur. Erkeklerin eğitimlerini tamamlayıp askerlik görevini yerine getirdikten ve iş sahibi olduktan sonra evlendirilmesi geleneksel toplumlarda daha çok kabul görse de erkek çocuklar da erken yaşta evlendirilmekte ve 'çocuk damat'lar karşımıza çıkmaktadır.

Söz konusu çalışma; içinde yaşadıkları toplumun sosyo-kültürel özellikleri bağlamında erken yaşta evlendirilen ya da evlenen hem kadınların hem de erkeklerin erken evliliğe iten nedenlerine, nasıl bir evlilik süreci geçirdiklerine, evlilik sonrası yaşamlarına ve evliliği nasıl anlamlandırdıklarına odaklanmaktadır. Bu çerçevede çalışma, erken evlilik, erken evliliğin nedenleri ve sonuçları konularından hareketle sosyo-kültürel özelliklerin erken evlilikte ne tür etkileri olduğunu tartışmaktadır.

\section{Erken Evlilikler}

Erken evlilik, on sekiz yaşından önce çocuğun fizyolojik ve psikolojik olarak gerekli olgunluğa hazır hale gelmeden yapılan evlilik olarak tanımlanmaktadır. Erken evlilikler, "çocuk evlilikler" ya da "çocuk gelinler" gibi farklı terimlerle de ifade edilmektedir (Orçan \& Kar 2008, 98; Boran et al. 2013, 1; Gezer-Tuğrul 2018, 6). Psikolojik ve fizyolojik gelişimini tamamlamadan çocuğun bilinçli rızası dışında yapılan bu evliliklerin büyük çoğunluğu "erken ve zorla yapılan evlilikler" olarak da tanımlanmaktadır. Çünkü çocukluk on sekiz yaşına kadar devam etmektedir. Nitekim bireyin bedensel, ruhsal ve zihinsel gelişimi bakımından belirli bir olgunluğa ulaşması on sekiz yaşına kadar gerçekleşebilmektedir (Özcebe \& Biçer 2013, 87). Erken yaşta yapılan evliliklere erkek çocuklarından çok kız çocuklarının maruz kalması ve kız çocuklarının bu durumdan daha çok etkilenmesinden dolayı "çocuk gelinler" kavramı ile daha sık karşılaşılmakta 
ve bu konuları kapsayan çalışmalara ağırlık verilmektedir (Boran et al. 2013, 1; Gezer-Tuğrul 2018, 6). Erkek çocuklarının da çocuk yaşta evlendirildiği durumlar olsa da askerlik görevi ve bir iş bulma gerekliliğinden dolayı onların kız çocuklarına nazaran daha ileri yaşta evlendirilmesi söz konusudur (Aydemir 2011, 1).

“Çocuk" ve "erken evlilik" kavramları kaynağına göre değişiklik gösteriyor olsa da, uluslararası anlamda, on sekiz yaşının altındaki bireyler "çocuk" olarak kabul edilmekte ve bu yaşın altında yapılan evliliklere de "erken evlilik" denilmektedir (Aydemir 2011, 31).

Birleşmiş Milletler Çocuk Hakları Sözleşmesi'nin 1. maddesinde “Bu sözleşme çocuğa uygulanabilecek olan kanuna göre daha erken yaşta reşit olma durumu hariç, on sekiz yaşına kadar her insan çocuk sayılır." denilerek çocuk kelimesinin kavramsal tanımı yapılmıştır (Birleşmiş Milletler, 1989). Türkiye'de yapılan çocuk tanımlarına baktığımızda ise Türk Medeni Kanunu'nun 11. maddesinde "Erginlik on sekiz yaşın doldurulmasıyla başlar" (Türk Medeni Kanunu, 2001); Türk Ceza Kanunu’nun 6. maddesinde “...Çocuk deyiminden; henüz on sekiz yaşını doldurmamış kişi, ...” (Türk Ceza Kanunu, 2004); Çocuk Koruma Kanunu'nun 3. Maddesinde ise "Daha ergin yaşta olsa da on sekiz yaşını doldurmamış kişi" (Çocuk Koruma Kanunu, 2005) ifadeleri yer almaktadır. Dolayısıyla on sekiz yaşını doldurmamış tüm bireyler çocuk sayılmakta ve 18 yaşın altındaki evlilikler de "erken evlilik" olarak değerlendirilmektedir. Ancak yine Türk Medeni Kanunu'nun 11. maddesinin devamında "Evlenme kişiyi ergin kılar."; 12. maddesinde "On beş yaşını dolduran küçük, kendi isteği ve rızasıyla mahkemece ergin kılınabilir." ve Türk Medeni Kanunu'nun 124. Maddesinde yer alan "Erkek veya kadın 17 yaş1nı doldurmadıkça evlenemez. Ancak hâkim olağanüstü durumlarda ve pek önemli bir sebeple 16 yaşını doldurmuş olan erkek veya kadının evlenmesine izin verebilir. Olanak bulundukça karardan önce ana ve baba veya vasi dinlenir” (Türk Medeni Kanunu, 2001) ifadeleriyle erken yaşta yapılan evliliklerin yolu açılmıştır.

Yukarıdaki ifadelerden hareketle Türk hukuk sisteminde yer alan "çocuk" ve buna bağlı olarak da "erken evlilik" tanımları arasında bir çelişki söz konusudur. Bu tanımlar cinsiyet farkı gözetmeksizin erkek ve kız çocukları için geçerlidir. Ancak var olan çelişkinin çözüme ulaşması Birleşmiş Milletler Çocuk Hakları Sözleşmesi'yle uyumlu hale getirilerek Türk hukuk sisteminde yer alan yasal düzenlemelerin daha iyi uygulanması ile mümkün olabilir.

\section{Erken Evliliklerin Nedenleri}

Erken evlilikler ya da diğer bir ifadeyle çocuk evlilikler gerek dünyada gerekse Türkiye'de önemini korumaya devam eden bir olgudur. Bu evliliklerin ortaya çıkmasında birçok neden bulunmaktadır. Erken evliliklerin nedenleri toplumdan topluma farklılık gösterse de temelde ekonomik ve sosyo-kültürel faktörler olarak karşımıza çıkmaktadır.

\section{Ekonomik Nedenler}

Erken yaşta yapılan evliliklerin büyük çoğunluğunda ailelerin ekonomik durumlarının düşük olduğu tespit edilmiştir. TBMM'nin 2010 yılında "Erken Yaşta Evlilikler Hakkında Inceleme Yapılmasına Dair Rapor"unda, “Özellikle sosyo-ekonomik durumu düşük aileler, kızlarını okula göndermemekte veya gönderse bile evlendirmek için okuldan geri almaktadırlar" tespiti yer almaktadır. "Kimi zaman sofradan bir tabağın eksilmesi fikri dahi aileler için küçük yaşta evlilikleri teşvik edici bir unsur olabilmektedir". Yine "Baba evinde çektiği maddi sıkıntılardan ve çocuk yaşta katlanmak zorunda bırakıldiğı iş yükünden kurtulacağını hayal eden kızlar evliliği bir çıkış yolu olarak görmektedirler" (TBMM, 2010).

Görüldüğü üzere erken evliliklerin nedenlerinden biri olan ekonomik problemlerin çözümü, çocuklarını bir an önce evlendirmeye yönelik uygulamalarla kendini göstermektedir. Geleneksel kültüre sahip ailelerde kız çocukları erkek çocuklarından daha az önemli görüldüğü için küçük 
yaşta başka bir aileye gelin olarak gönderilmektedir. Bu aileler ekonomik yükten kısmen kurtulmak ya da rahatlamak için daha iyi şartlara sahip olan ailelere para ya da mal karşılığında kız çocuklarını kendilerinden yaşça çok büyük olan erkeklerle evlendirmektedir. Bu evlilikler de gelenek adı altında başlık parası, berdel, beşik kertmesi gibi uygulamalarla normalleştirilmektedir (Aydemir 2011, 16). Ekonomik bir iş gücü oluşturan bu evlilikler ekonomik bir gelir kaynă̆1 olarak görülmektedir (UNICEF 2001, 6).

\section{Sosyo-Kültürel Nedenler:}

Erken evliliklerin nedenleri ele alındığında özellikle içinde bulunulan toplumun sosyo-kültürel özellikleri dikkat çekmektedir. Çünkü erken evliliklerin yaygın olduğu yerlerde yapılan bu evlilikler kültürel değerler ve dini pratikler nedeniyle bir sorun olarak görülmemekte, geleneklerin bir parçası olarak kabul edilmektedir. Çünkü ataerkil ve geleneksel yapı küçük yaşta evliliği kabul edilen bir olgu haline getirmektedir. J. Joel Moss, sanayileşme süreciyle birlikte toplumlarda evlilik yaşının farklılık göstermesinin yanı sıra evlilik yaşına dair algıların o toplumun kültürel değerlerinde var olduğunu ileri sürmektedir (Moss 1965, 98; Aydemir 2011, 18). Örneğin Pakistan ve Hindistan'ın bazı bölgelerinde on beş - on altı yaşlarına gelmiş kız çocukları birer yetişkin olarak kabul edilmekte ve bunların evlilikleri normal kabul edilmektedir (Aydemir 2011, 22). Bunun yanı sıra zorunlu göç sebebiyle insanların yaşadığı ekonomik ve sosyokültürel değişim de erken yaşta evlilikleri arttıran etmenler arasında yer almaktadır (Özcebe \& Biçer 2013, 90).

Çocuk evliliklere yol açan diğer bir neden de hem resmi hukukta hem de geleneksel ritüellerde yer alan uygulamalardır. Resmi hukukta yer alan yasalar erken yaşta evliliği yasaklayan hükümler içermektedir. Ancak Türkiye de dahil olmak üzere bir çok ülkede, erken yaşta yapılan evlilikler resmi olarak yasak olmasına karşın gerek gündelik yaşam pratikleri gerekse geleneksel uygulamalar bu evliliklerin sürmesine yol açmaktadır. Bu uygulamaların başında da dini nikâh gelmektedir (Şen 2014, 38-39). Erken yaşta yapılan evliliklerde dini nikâhlar resmi nikâha göre daha fazla tercih edilmektedir. Bu dini ritüelle birlikte erken yaşta yapılan evlilikler geçerli k1lınmaktadır (Erdoğan, n.d.).

Erken yaşta evliliklerin ortaya çıkmasında etkili olan bir diğer neden eğitim faktörüdür. Ailenin eğitim düzeyi ile sosyo-kültürel (UNICEF 2005, 25) ve ekonomik faktörler de erken evlilikleri teşvik edici bir rol oynamaktadır (Yüksel-Kaptanoğlu \& Ergöçmen 2012, 133). Geleneksel toplum yapısı ve o toplumlarda görülen ataerkillik, "kadının yeri, kocasının yanıdır" söyleminden hareketle kız çocuğunun, kocasının evine ait olduğu ve kız çocuklarının bir gün evlenerek baba evini terk edeceği görüşüyle de kız çocuklarının eğitimine önem verilmemektedir. Ataerkil ailelerde erkeklerin belirli bir eğitim alıp iş sahibi olduktan sonra ileri yaşta evlenmesi normal karşılanmaktadır. Buna karşılık aynı ataerkil ailelerde kız çocuklarının eğitimine yatırım yapılmamakta, çalışma hayatına katılmalarına izin verilmemekte, kadın ve erkek arasındaki yaş farkının önemli olmaması nedeniyle de kız çocuklarını kendilerinden yaşça büyük erkeklerle erken yaşta evlendirilme eğilimi görülmektedir. Bu eğilim doğrultusunda geleneksel toplumlarda kız çocuklarının toplumdaki eşitsiz konumları pekiştirilmekte ve hayat tercihleri azaltılmaktadır (Aydemir 2011, 18, 19, 24). Bu da erken evliliklerde toplumsal cinsiyet eşitsizliğinin de önemli bir rolü olduğunu göstermektedir (Raj et al. 2011, 1-4). Diğer bir ifadeyle erken yaşta yapılan evliliklerde geleneksel toplum yapısı ve ataerkillik, kadınlar ve erkekler arasındaki eşitsizlikleri ortaya çıkarmaktadır. Örneğin Türkiye'nin bazı bölgelerinde sahip olunan sosyo-kültürel anlamlar ve değerler, aile soyunu erkek çocuğunun devam ettireceği düşünüldüğü için erkek çocuğuna önem verilmesi ve kı çocuğunun ikinci plana itilmesi cinsiyetler arası eşitsizliği ortaya koymaktadır. Özellikle kız çocuklarının erken yaştan itibaren evlilik düşüncesi içerisinde yetiştirilmeleri, "yaşın geçerse kimse almaz", "bir an önce evlen ve 
çocuk yap" şeklindeki geleneksel söylemler, kadından beklenen cinsel rolün evlilik olduğu yönündeki algı namus algısıyla da bütünleştirilerek geç evlenme halinde toplumsal hayatta zorlanacaklarına dair baskılar, aile içi şiddet, erken evliliklerin artmasına neden olabilmektedir (Şen 2014, 36-37).

Sonuç olarak erken evliliklerin ortaya çıkmasında etkili olan birçok neden bulunmaktadır. Ancak bu nedenler toplumdan topluma değişiklik göstermektedir. Ekonomik faktörler, eğitim düzeyinin düşüklüğü, toplumsal cinsiyet eşitsizliği, ataerkillik, kültürel değerler ve geleneksel ritüeller, aile içi şiddet, toplumsal baskı vb. gibi birçok neden kız çocuklarının erken yaşta evlendirilmesine zemin hazırlamakta, temelde sosyal ve kültürel bir sorun olarak karşımıza çıkmaktadır.

\section{Erken Evliliklerin Sonuçları}

Erken evliliğe neden olan faktörler aynı zamanda benzer birçok olumsuz sonucu da beraberinde getirmektedir. Erken yaşta yapılan evlilikler çocukların eğitimlerinin yarıda kalmasına, eğitim firsatlarından yararlanamamalarına neden olmaktadır. Bu evlilikler çocukların kamusal alan içerisine girmesine izin vermemekte, onları özel alana doğru itmektedir (Burcu et al. 2015, 86). Eğitim ve istihdamda erkeklerin gerisinde kalma, toplumsal dışlanma, aile içi şiddet ve baskıya maruz kalma gibi birçok olumsuz sonuçtan daha çok kadınların etkilenmesi erken evlilik sorununun temelinde toplumsal cinsiyet eşitsizliğinin yattığını göstermektedir (Yüksel-Kaptanoğlu \& Ergöçmen 2012, 131).

Erken yaşta evlilik yapan çocuklar, çocukluklarını yaşayamamaktadırlar. Bunun yanı sıra kendilerinde fiziksel ve psikolojik rahatsızliklar (le Strat et al. 2011, 524-530; Raj et al. 2013, 14-15) ortaya çıkmaktadır. Diğer bir ifadeyle erken yaşta evlenen çocuklar hazır olmadıkları yaşta ev içi rolleri üstlenmek durumunda kalmakta ve olumlu bir sosyalleşme süreci geçirememektedir. Bu süreçte çocuklar, aile ve arkadaş çevrelerinden koparılmakta, evde sömürüye, şiddete, istismara ve yoksulluğa açık hale gelmektedir (Aydemir 2011, 23).

Erken evlilikler, çocuk ile insan hakları ihlali (UNICEF 2006, 17; UNFPA 2012, 8-15) ve çocuk istismarının da en açık görünür biçimidir (Bates et al. 2007, 38; Hervish \& FeldmanJacobs 2011, 3). Bu durum özellikle kız çocuklarını fazlasıyla etkilemektedir. Türk Ceza Kanunu'nun "Çocukların Cinsel İstismarı" başlığ1 altında 103. maddesinde "Onbeş yaşııı tamamlamamış veya tamamlamış olmakla birlikte fiilin hukuki anlam ve sonuçlarını algılama yeteneği gelişmemiş olan çocuklara karşı gerçekleştirilen her türlü davranış" ifadesi yer almaktadır (Türk Ceza Kanunu, 2004). Buna rağmen Türkiye'de her üç kadından biri erken evlilik yapmaktadır (Ova 2014, 242) ve UNICEF 2014 verilerine göre Türkiye'de erken evlilik gerçekleştiren kadınların oranı \%14'tür (UNICEF 2014, 82). Dolayısıyla erken yaşta yaşanan cinsellik beraberinde, erken ve sık doğumları getirmektedir. Erken hamilelikte düşük yapma ve erken doğum riski normal hamile kadınlara göre dört kat daha fazladır. Bu da hayati tehlikelerinin daha fazla olduğunu göstermektedir. (Ova 2014, 241). Bu süreçte "çocuk anneler", doğum riski, ya da kalıcı hastalıklar gibi ciddi risklerle de karşı karşıya kalmaktadırlar (Orçan \& Kar 2008, 98). Nitekim hem fiziksel hem de psikolojik olarak hazır olmayan kız çocuklarının erken yaşta hamilelikleri, onlarda hem bedenen hem de ruhen hasar birakmakta ve bunun sonucu olarak da anne-çocuk ölüm oranlarında artış gözlenmektedir (Aydemir 2011, 23).

Özetle erken evlilikler kız çocuklarının eğitim haklarını ellerinden almakta, onlara ev içi sorumluluklar yüklemekte, onları aile içi şiddet ve baskıya maruz bırakmakta ve erken yaşta yaşanan cinsellikle birlikte anne çocuk sağlığını tehlikeye sokmaktadır. Dolayısıyla erken evliliklerin çocuk ve insan hakları ihlali olarak görülmesi gerekmektedir. 


\section{Araştırmanın Yöntemi}

Araştırmada sosyo-kültürel özellikler bağlamında erken evlilik yapan kadın ve erkekler ele alınmıştır. Bu çerçevede erken evlilik yapan katılımcıların sosyo-kültürel deneyimleri, erken evliliğe iten nedenleri, evliliği anlamlandırma biçimleri, ve aile içi ilişkileri onların bakış açısıyla anlaşılmaya çalışılmıştır. Araştırmada nitel araştırma yöntemi kullanılmıştır. Bu yöntem dahilinde veri toplanırken derinlemesine görüşme tekniği tercih edilerek yarı-yapılandırılmış görüşme formu hazırlanmıştır. Katılımcıların belirlenmesinde kartopu örneklem tekniği kullanılmış olup görüşmeler 8 kadın, 8 erkek olmak üzere toplam 16 katılımcı ile Ağrı ilinde gerçekleştirilmiştir. Görüşmelere başlamadan önce katılımcılarla tanışılarak araştırmacılarla katılımc1lar arasında güven ortamı oluşturulmaya çalışılmıştır. Görüşmeler 2018 yılı Ocak ve Şubat aylarında 30-90 dakika aralığında yüz yüze gerçekleştirilerek katılımcıların kendi doğal ortamlarında yapılmış ve sohbet havası yaratılmaya çalışılmıştır. Görüşmelerin ses kaydına alınması için tüm katılımcıların izinleri istenmiş olup 14 katılımcı ile yapılan görüşmelerde ses kayıt cihazı kullanılmıştır. Diğer 2 katılımcı ses kayıt cihazı kullanılmasına müsaade etmediği için bu katılımcılarla yapılan görüşmelerde ayrıntılı notlar alınmıştır. Bunun yanı sıra görüşmeler tamamlandıktan sonra gerçekleşen sohbetler ve gözlemler de not edilmiştir.

Araştırmada elde edilen verilerin analizinde derleme, parçalarına ayırma, yeniden birleştirme, verilerin yorumlanması ve sonuç aşamaları (Burcu-Sağlam 2018, 126-130) kullanılmıştır. Bu bağlamda elde edilen verilerin çözümlenmesine öncelikle ses kayıtlarının deşifre edilmesi ve saha notlarının toparlanmasıyla başlanmıştır. Ardından veriler, kodlama işlemi yapılmaksızın parçalarına ayrılarak irdelenmiştir. Bu işlemde tutarsızlık ve mantık hatalarından kaçınabilmek için orijinal verilere sürekli dönülmüş ve veriler defalarca okunarak çözümlenmeye çalışılmıştır. Bu çözümleme araştırmanın verilerine sadık kalınarak gerçekleştirilmiş̧ir. Parçalarına ayrılan veriler sonrasında birbirleriyle ilgi ve bağlantı durumlarına göre bir araya getirilerek yorumlanmış ve araştırmanın bulgularından sonuç ve değerlendirme kısmında kısaca bahsedilmiştir.

\section{Araştırma Bulguları: Ağrı'da Erken Evlilik Yapan Çocuklar}

\section{Demografik Özellikler}

Araştırma kapsamında katılımcıların yaşları, şu anki medeni durumları, gelirleri, kendilerinin, ebeveynlerinin ve eşlerinin eğitim durumları ile evlenme yaşları incelenmiştir.

Tablo 1. Erkek Katılımcıların Demografik Özellikleri

\begin{tabular}{|c|c|c|c|c|c|c|c|c|}
\hline & E1 & E2 & E3 & E4 & E5 & E6 & E7 & E8 \\
\hline Yaş & 37 & 45 & 23 & 40 & 32 & 34 & 47 & 34 \\
\hline $\begin{array}{l}\text { Eğitim } \\
\text { Durumu }\end{array}$ & Üniversite terk & İlkokul & Ortaokul & Lise & Ortaokul & Lise & Ortaokul & Lise \\
\hline $\begin{array}{l}\text { Medeni } \\
\text { Durum }\end{array}$ & Evli & Evli & Evli & Evli & $\begin{array}{l}\text { Bekar } \\
\text { (Boşanmış) }\end{array}$ & Evli & $\begin{array}{l}\text { Evli } \\
\text { (2.evlilik, ilk } \\
\text { eşi vefat } \\
\text { etmiş.) }\end{array}$ & Evli \\
\hline $\begin{array}{l}\text { Eşinin } \\
\text { Eğitim } \\
\text { Durumu }\end{array}$ & İlkokul & $\begin{array}{l}\text { İlkokul } \\
\text { terk }\end{array}$ & $\begin{array}{l}\text { Okur-yazar } \\
\text { değil }\end{array}$ & $\begin{array}{l}\text { Okur-yazar } \\
\text { değil }\end{array}$ & İlkokul & $\begin{array}{l}\text { İlkokul } \\
\text { terk }\end{array}$ & Lise & İlkokul \\
\hline $\begin{array}{l}\text { Annesinin } \\
\text { Eğitim } \\
\text { Durumu }\end{array}$ & $\begin{array}{l}\text { Okur-yazar } \\
\text { değil }\end{array}$ & $\begin{array}{l}\text { Okur- } \\
\text { yazar değil }\end{array}$ & $\begin{array}{l}\text { Okur-yazar } \\
\text { değil }\end{array}$ & $\begin{array}{l}\text { Okur-yazar } \\
\text { değil }\end{array}$ & $\begin{array}{l}\text { Okur-yazar } \\
\text { değil }\end{array}$ & İlkokul & $\begin{array}{l}\text { Okur-yazar } \\
\text { değil }\end{array}$ & $\begin{array}{l}\text { Okur- } \\
\text { yazar değil }\end{array}$ \\
\hline $\begin{array}{l}\text { Babasının } \\
\text { Eğitim } \\
\text { Durumu }\end{array}$ & $\begin{array}{l}\text { Okur-yazar } \\
\text { değil }\end{array}$ & $\begin{array}{l}\text { Okur- } \\
\text { yazar değil }\end{array}$ & $\begin{array}{l}\text { Okur-yazar } \\
\text { değil }\end{array}$ & Ortaokul & $\begin{array}{l}\text { Okur-yazar } \\
\text { değil }\end{array}$ & Ortaokul & $\begin{array}{l}\text { Okur-yazar } \\
\text { değil }\end{array}$ & $\begin{array}{l}\text { Okur- } \\
\text { yazar değil }\end{array}$ \\
\hline Geliri & $4500 \mathrm{TL}$ & $3000 \mathrm{TL}$ & $5000 \mathrm{TL}$ & $2000 \mathrm{TL}$ & $\begin{array}{l}3000-3500 \\
\text { TL }\end{array}$ & $4000 \mathrm{TL}$ & $4000 \mathrm{TL}$ & $\begin{array}{l}2000-2500 \\
\text { TL }\end{array}$ \\
\hline Evlenme & 17 & 16 & 17 & 16 & 17 & 15 & 17 & 15 \\
\hline
\end{tabular}




\begin{tabular}{|l|l|l|l|l|l|l|l|l|}
\hline Yaş1 & & & & & & & & \\
\hline $\begin{array}{l}\text { Annesinin } \\
\text { Evlenme } \\
\text { Yaş1 }\end{array}$ & $\begin{array}{l}\text { 2 anne. Kendi } \\
\text { annesi 18-19 }\end{array}$ & 14 & 13 & 22 & $\begin{array}{l}2 \text { anne. } \\
\text { Kendi annesi } \\
15\end{array}$ & $\begin{array}{l}19 \\
\text { Kendi } \\
\text { annesi } 15\end{array}$ & 14 \\
\hline $\begin{array}{l}\text { Babasının } \\
\begin{array}{l}\text { Evlenme } \\
\text { Yaş1 }\end{array}\end{array}$ & 45 & 30 & 22 & 24 & 40 & 22 & 40 & 23 \\
\hline $\begin{array}{l}\text { Eşinin } \\
\text { Evlenme } \\
\text { Yaş1 }\end{array}$ & 17 & 16 & 15 & 28 & 17 & 15 & 19 & 14 \\
\hline
\end{tabular}

Tablo 1'e göre, erkek katılımcıların demografik özellikleri incelendiğinde katılımcıların 23-47 yaş aralığında oldukları görülmektedir. Bunların yedisi evli iken bir katılımeı ise boşanmıştır. Evli olan erkek katılımcılardan biri erken evlilik yaptığı ilk eşi vefat ettiği için ikinci evliliğini gerçekleştirmiştir. Katılımcılardan biri ilkokul, üçü ortaokul, dördü lise mezunudur. Lise mezunu olan katılımcılardan biri ise üniversiteyi yarıda bırakmıştır. Dolayısıyla araştırmaya çeşitli eğitim düzeylerinden katılımcılar dâhil edilmiştir. Yedi katılımcının eğitim düzeylerinin, eşlerinin eğitim düzeylerinden yüksek olduğu görülmektedir. Yalnızca bir katılımcının eşinin eğitim düzeyi, kendisininkinden yüksektir. Katılımcıların anne ve babalarının eğitim durumu düşük seviyededir. Katılımcıların yedisinin annesi okur-yazar değildir, biri ise ilkokul mezunudur. Dolayısıyla annelerinin eğitim durumlarında okur-yazar olmama durumu hâkim görünmektedir. Katılımcıların babalarının eğitim durumlarına bakıldığında ise, altısı okur-yazar değildir, ikisi ise ortaokul mezunudur. Buna göre araştırmada yer alan erkek katılımcıların sadece ikisinin babalarının eğitim durumu annelerinin eğitim durumlarından yüksektir. Burada dikkat çeken diğer bir nokta ise, üç katılımcının iki annesinin olmasıdır. Bu da sosyo-kültürel yapı içerisinde çok eşliliğin ve dini nikâh ya da nikâhsız yaşamanın olduğunu göstermektedir.

Tablo 1'e göre, katılımcıların önemli bir diğer demografik özelliği, gelir durumlarıdır. Farklı meslek gruplarından olan erkek katılımcıların gelir düzeyleri 2000 TL ile 5000 TL aralığında değişkenlik göstermektedir. Dolayısıyla katılımcıların belirli bir gelire sahip olduğu ve gelir düzeylerinin çeşitlilik gösterdiği söylenebilmektedir.

Erkek katılımcıların evlilik yaşına bakıldığında ise ikisinin 15, ikisinin 16, dördünün 17 yaşında evlendikleri görülmektedir. Katılımcıların beşinin annesi erken evlilik gerçekleştirmiştir. Eşlerinden ikisinin reşit olduğu, altısının ise erken yaşta evlilik yaptığı dikkat çekmektedir. Buna göre ikisi hariç, altı katılımcının eşlerinin de erken yaşta evlilik yaptığı görülmektedir.

Tablo 2. Kadın Katılımcıların Demografik Özellikleri

\begin{tabular}{|l|l|l|l|l|l|l|l|l|}
\hline & K1 & K2 & K3 & K4 & K5 & K6 & K7 & K8 \\
\hline Yaş & 28 & 35 & 40 & 19 & 32 & 41 & 40 & 44 \\
\hline $\begin{array}{l}\text { Eğitim } \\
\text { Durumu }\end{array}$ & İlkokul terk & Ortaokul & İlkokul & İlkokul & $\begin{array}{l}\text { İlkokul } \\
\text { terk. }\end{array}$ & İlkokul & Üniversite & Lise \\
\hline $\begin{array}{l}\text { Medeni } \\
\text { Durum }\end{array}$ & Evli & Evli & $\begin{array}{l}\text { Bekar } \\
\text { (Boşanmış) }\end{array}$ & Evli & Evli & Evli & $\begin{array}{l}\text { Evli } \\
\text { (Boşanmış, } \\
\text { 2. evlilik) }\end{array}$ & Evli \\
\hline $\begin{array}{l}\text { Eşinin } \\
\text { Eğitim } \\
\text { Durumu }\end{array}$ & Ortaokul & Lise & İlkokul & $\begin{array}{l}\text { Okur-yazar } \\
\text { değil }\end{array}$ & Lise & İlkokul & Lise & $\begin{array}{l}\text { İlkokul } \\
\text { terk }\end{array}$ \\
\hline $\begin{array}{l}\text { Annesinin } \\
\text { Eğitim } \\
\text { Durumu }\end{array}$ & $\begin{array}{l}\text { Okur-yazar } \\
\text { değil }\end{array}$ & $\begin{array}{l}\text { Okur-yazar } \\
\text { değil }\end{array}$ & $\begin{array}{l}\text { Okur-yazar } \\
\text { değil }\end{array}$ & $\begin{array}{l}\text { Okur-yazar } \\
\text { değil }\end{array}$ & $\begin{array}{l}\text { Okur-yazar } \\
\text { değil }\end{array}$ & $\begin{array}{l}\text { Okur-yazar } \\
\text { değil }\end{array}$ & Lise & $\begin{array}{l}\text { Okur- } \\
\text { yazar } \\
\text { değil }\end{array}$ \\
\hline $\begin{array}{l}\text { Babasının } \\
\text { D̆itim } \\
\text { Durumu }\end{array}$ & İlkokul & Ortaokul & $\begin{array}{l}\text { Okur-yazar } \\
\text { değil }\end{array}$ & $\begin{array}{l}\text { Okur-yazar } \\
\text { değil }\end{array}$ & Lise & $\begin{array}{l}\text { Okur-yazar } \\
\text { değil }\end{array}$ & Üniversite & $\begin{array}{l}\text { Okuz- } \\
\text { yazar } \\
\text { değil }\end{array}$ \\
\hline
\end{tabular}




\begin{tabular}{|l|l|l|l|l|l|l|l|l|}
\hline Geliri & $\begin{array}{l}5000 \mathrm{TL} \\
\text { (Eşinin) }\end{array}$ & $\begin{array}{l}2000 \mathrm{TL} \\
\text { (Eşinin) }\end{array}$ & $\begin{array}{l}\text { 2000-2500 } \\
\text { TL } \\
\text { (Kendisinin) }\end{array}$ & $\begin{array}{l}1000-1500 \\
\text { TL } \\
\text { (Kayınvalide } \\
\text { sit+kendisi) }\end{array}$ & $\begin{array}{l}5000 \mathrm{TL} \\
\text { (Eşi+kendisi) }\end{array}$ & $\begin{array}{l}\text { Günlük } \\
\text { kazanç } \\
\text { nedeniyle } \\
\text { belli değil }\end{array}$ & $\begin{array}{l}\text { 2000-2500 } \\
\text { TL } \\
\text { (Kendisinin) }\end{array}$ & $\begin{array}{l}\text { 2500- } \\
\text { 3000 TL } \\
\text { (Eşinin) }\end{array}$ \\
\hline $\begin{array}{l}\text { Evlenme } \\
\text { Yaş1 }\end{array}$ & 17 & 17 & 17 & 15 & 15 & 16 & 15 & 16 \\
\hline $\begin{array}{l}\text { Annesinin } \\
\text { Evlenme } \\
\text { Yaş1 }\end{array}$ & $16-17$ & 13 & $12-13$ & 17 & $\begin{array}{l}\text { Bilmiyor } \\
\text { (18'den } \\
\text { ônce) }\end{array}$ & $\begin{array}{l}2 \text { anne. } \\
\text { Kendi } \\
\text { annesi } 17\end{array}$ & 14 & 17 \\
\hline $\begin{array}{l}\text { Babasının } \\
\text { Evlenme } \\
\text { Yaş1 }\end{array}$ & $19-20$ & 18 & $20-21$ & 17 & Bilmiyor & 16 & 25 & 22 \\
\hline $\begin{array}{l}\text { Eşinin } \\
\text { Evlenme } \\
\text { Yaş1 }\end{array}$ & 23 & 18 & 18 & 18 & 25 & Bilmiyor & 26 & 18 \\
\hline
\end{tabular}

Tablo-2'ye göre kadın katılımcıların demografik özellikleri incelendiğinde ise katılımcıların 1944 yaş aralığında oldukları görülmektedir. Bunların yedisi evli, biri eşinden boşanmıştır. Evli olan katılımcılardan biri ise erken yaşta gerçekleştirdiği ilk evliliğini boşanma ile sonlandırmış ve görüşmeler sırasında ikinci evliliğini gerçekleştirmiştir. Katılımcıların beşi ilkokul, biri ortaokul, biri lise, biri de üniversite mezunudur. Dolayısıyla araştırmaya çeşitli eğitim düzeylerinden katılımcılar dahil edilmiştir. Dört katılımcının eşlerinin eğitim düzeyi, kendilerininkinden düşük olup ikisinin eğitim düzeyi eşleri ile denk, ikisinin eğitim düzeyi ise eşlerinden daha düşüktür. Katılımcıların eğitim durumları annelerinin eğitim durumlarından daha yüksektir. Annelerinin yedisi okur-yazar değildir, biri ise lise mezunudur. Dolayısıyla annelerinin eğitim durumlarında okur-yazar olmama durumu hakim görünmektedir. Katılımcıların babalarının eğitim durumuna bakıldığında ise dördünün babasının eğitim durumu, annelerinin eğitim durumundan daha yüksek iken dördünün babasının ve annesinin eğitim durumu ise denktir. Buna göre, araştırmada yer alan kadın katılımcıların babalarının eğitim durumlarının annelerinin eğitim durumlarından düşük olmadığ 1 görülmektedir. Burada da dikkat çeken diğer bir nokta erkek katılımcılarda olduğu gibi kadın katılımcılardan birinin iki annesinin olmasıdır. Dolayısıyla çok eşliliğin ve dini nikâh ya da nikâhsız yaşama olgusunun olduğu bir sosyo-kültürel yapıdan bahsedilebilmektedir.

Tablo-2'ye göre, katılımcıların demografik özellikleri içerisinde önemli bir unsur da gelirdir. Ev hanımı olan kadın katılımcılara gelir durumu sorulduğunda bunlar eşlerinin gelirini ifade ederken çalışan kadın katılımcılar ise gelirleri belirli ise kendi gelirlerini ama gelirleri belirsiz ise hane içerisindeki geliri ifade etmişlerdir. Buna göre, kadın katılımcıların da gelirlerinin 1000 TL ile 5000 TL arasında değişkenlik gösterdiği görülmektedir. Dolayısıyla araştırmaya farklı gelir düzeylerinden katılımcıların dahil edildiği söylenebilmektedir.

Tablo-2'ye göre, kadın katılımcıların evlilik yaşlarına bakıldığında ise katılımcıların üçünün 15, ikisinin 16 ve üçünün ise 17 yaşında evlendikleri görülmektedir. Katılımcıların tamamının annesi erken evlilik gerçekleştirirken katılımcıların sadece ikisinin babası erken evlilik gerçekleştirmiştir. Katılımcıların eşlerinin evlenme yaşlarına bakıldığında ise hepsinin reşit olduktan sonra evlendikleri görülmektedir. Buradan da katılımcıların eşlerinin kendilerinden yaş olarak büyük olduğu ve erken evlilik gerçekleştirmedikleri sonucu çıkmaktadır.

\section{Erken Evliliğe Yönelik Bakış Açısı}

Erken evlilik, daha önce de belirtildiği gibi 18 yaşından önce yapılan evlilikleri kapsamaktadır. Kanunen 18 yaşının altındaki kişiler çocuk sayılmaktadır. Dolayısıyla bu yaşlarda yapılan evliliklerde evlenen kişiler çocukluklarını yaşayamamakta ve evliliğe dair sorumluluklar yüklenmek zorunda bırakılmaktadırlar. Bu nedenlerle araştırmaya katılan kadın katılımcıların 
tamamı ve erkek katılımcıların beşi erken evliliğe karşı çıkmışlardır. Onlara göre erken evlilik şu şekillerde ifade edilmiştir:

K6: "Ölmek demek. İstediğini yaşayamıyorsun. Çocukluğunu yaşayamıyorsun. Gençliğini yaşamıyorsun. Kendini savunamıyorsun. Hayatında sana seçim şansi vermiyorlar ki”.

E6: "Erken evlenmek iyi bir şey değil ben onu söyleyeyim öncelikle. Yani anne babaların çocuklarına karşı sorumsuzluklarıdır. Bir çocuğun 15-16 yaşında "Ben evleneceğim." dediğinde, "Evet." diyen bir ya da evlendiren anne-babalar yani günümüz şartlarında gerçekten sorunsuz anne babalardır. Evlenen insan geri zekalıdır bence. Çünkü bilmiyorsun ve bilmediğin bir yola giriyorsun. Yani derinliğinin ne kadar olduğunu bilmediğin bir suya giriyorsun ve çırpın diyorsun sürekli boğulmamak için, öyle bir şey”.

Katılımcıların ifadelerinde özellikle erken evliliğe yönelik "ölüm” vurgusu dikkat çekmektedir. Buna göre, çocukluğun yaşanamaması ve evlilikle birlikte yeni sorumluluklar altında kalınması hayatın bitmesiyle özdeşleştirilmektedir. Böyle bir yaşamın sorumlusu olarak da ebeveynler gösterilmektedir. Bu görüşlerin aksine, erkek katılımcıların üçü erken evliliğe 1lımlı yaklaşmışlardır. Bunun nedeni de evlilik yaşına dair düşüncelerinde daha net ifade bulmaktadır. Buna göre, erken evliliklerde evliliğin erken yaşlarda yapılmış olması, evliliği gerçekleştiren kişilerin çocuklarıyla daha fazla zaman geçirmeleri, onların büyüdüklerini görmeleri, onlarla beraber kendilerinin de büyümeleri bağlamında olumlu nitelikleriyle değerlendirilmiştir.

E1: "Evlilikte yaş elbette çok önemli. Şimdi çocuk ruhlu olmak hem erkek için hem kadın için sorun oluyor. Yani olgun düşünememe... Ondan sonra belli kararlarda sikıntılı bir durum. Yani gençsin, yani tez canlısin, kanın kaynıyor. Yani şimdi oradaki evlilik ne kadar doğru olur. Ama bir yandan baktı̆̆ın zaman erken yaşta sorumluluk almanın güzel tarafları da var. Ama yine de baktığın zaman o yaş evlilik yaşı değil. 16-17 yaş çok erken bir yaş. Şu an için düşündügümde bazen diyorum erken evlenerek iyi yaptım. Çünkü çocuklarım benimle yetişti. Hatta şu an bir kızım da nişanlı”.

Erkek katılımcılar, ideal evlilik yaşını yaşanılan coğrafya, askerlik gibi durumlara göre değerlendirmişlerdir. Dolayısıyla yaşanılan bölgenin sosyo-kültürel yapısı evlilik yaşı üzerinde belirleyici olmaktadır. Bu doğrultuda, katılımcılar kadınların ideal evlilik yaşını erkeklerin ideal evlilik yaşına göre daha erken yaşlarda belirtmişlerdir. Bu durum, kadınların erkeklerden daha erken olgunlaşmalarıyla açıklanmıştır. Erkeklerin olgunlaşmaları ise askerlik sürecini tamamlamış olmaları ile ölçülmüştür. Askerliğini yapmış olan bir erkek evliliğe hazır olarak görülmüştür.

E1: "Evlilik yaşı biraz, coğrafyaya göre değişir. Mesela bölgemiz şartlarında bence 21-23 ideal bir yaştır. Çünkü fazlası sıkıntı oluyor. Yani otuz yaşında bir arkadaşım evlendi çok sılkıntı yaşadı. Bence ideali 21-23". E6: "İdeal yaş erkek ve kadında değişir. Kadının 18-19 olması hani normaldir. Erkekte 22-24 yaşına kadar yani evli olmanın sorumluluğunu ben bilmiyordum. Klzlar mental olarak erkeklerden biraz daha olgun olarak düşünebiliyor. Yeri geldiğinde ailedeki herhangi bir sorunu çözebilecek bir güce sahiptir. Bir kız 18-19 yaşlarında olmall, bir erkekte 2224 yaş arası evlenme yaşı olabilir. Çünkü ancak o yaşlarda bir şeylerin bilincinde yani hani farkinda oluyorsun". 
Kadın katılımcılar da erkek katılımcılar gibi evlilik yaşının daha yüksek olması gerektiğini düşünmüşlerdir. Burada hem kendileri hem de eşlerinin olgunlaşması üzerine vurgu yapmışlardır. Kadın katılımcılar, erken evlilik ile çocukluğun yaşanamaması ve kişilik gelişiminde çevrenin belirleyiciliğinin ön plana çıkmasını belirterek erken evliliğe karşı çıkmışlardır. Bu gerekçelerle evlilik yaşı noktasında olgunlaşmak, eğitim, iş ve meslek sahibi olmak vurgulanmıştır.

K5: "Önemli. Çünkü çocuk yaşta evleniyorsunuz hiç bilinçli değilsiniz, hiçbir şey bilmiyorsunuz. Çocuksunuz ya küçücüksünüz evlenirken. Akllnızın yarısı oyuna gidiyor o zamanlar. Ben öyleydim, aklım hep oyundaydı. Ben evlendikten sonra kendi kalıbımdan çıkıp onların kalıbına girdim. Kendiniz olamıyorsunuz onlar sizi yönetiyor hep... Bence sinır 20 yaş olmalı. 20 yaşııdaysanız kendinizi biliyorsunuzdur. Eşiniz size hüküm süremiyor. Siz kendi kararlarınızı verebiliyorsunuz. Ama küçük yaşta evlenince siz başka kalıba giriyorsunuz, küçüksünüz mecbur kılınıyorsunuz. Bu durum da ister istemez ruhsal problemler yaratiyor sizde. Küçük yaşta olunca eş sizi cahil görüyor, kaynana sizi cahil görüyor, hepsi sizi yönetmeye çalışıyor... Önemli. Askerlik yapmayan bir erkek cahildir, toydur, kafası bir karış havadadır bence. Çünkü askerlik yapan bir erkek daha çabuk olgunlaşlyor".

K8: "Evet, çok çok önemlidir. Çünkü yani yaş ilerledikçe insan olgunlaşır ve daha çok hayat tecrübesi edinir, her şeyin farkında olur, doğruyu yanlışı, iyiyi kötüyü bilir... Bence evlilik yaşı 26-27 olmalıdır. Bu kaz erkek için fark etmez ikisi de üniversiteyi bitirsin iş güç sahibi olsun öyle evlensin. Hayat zor tek maaşla insan evi geçindiremez. Bu yaşlarda evlenilirse hem her şeyin farkında olmuş olur, hem de eğitimlerini tamamlamış meslek sahibi olmuş olurlar. Hele ki eğitim bir evlilik için çok önemlidir... Tabii önemli hem de çok fazla önemli. Çünkü askerlikte bir erkek disiplinli olmayı öğreniyor. Ama bunun dişında, kocam biz evliyken askere gitti çok zorluk yaşadım. Bir şeye ihtiyacım olunca kayınpederimden falan isteyemiyordum utaniyordum. Paraya ihtiyacım olsa isteyemiyordum. Kocam askerdeyken çocuklarımı vardı onlar babaların özlüyordu, onlar bir şey istese alamıyordum param yoktu. Hem çok hasretlik çektik hem de çok parasızlık yaşadık. O yüzden erkek askere gitsin gelsin sonra evlensin".

Dolayısıyla evliliklerin gerçekleştirilmesinde toplumsal açıdan erkeklerin askerliğini yapmış olmaları beklenmektedir. Erkeklerin yaptıkları erken evliliklerde ya da askerlik öncesi gerçekleştirdikleri evliliklerde askerlik açısından daha sonraki zamanlarda eşten ve çocuklardan ayrı kalma nedeniyle zorluklar yaşanabilmektedir. Katılımcıların askerlik vurguları neticesinde araştırmada da askerliğin evlilik açısından nasıl bir öneminin olduğuna da bakılmıştır. Hem kadın katılımcılar hem de erkek katılımcılar erkeklerin askerlik yapmasını önemli görmüş ve askerlikten sonra evlenilmesi gerektiğini düşünmüşlerdir. Erkek katılımcılar, askerlikle ilgili sorumluluk ve disiplin duygusunun gelişmesi gibi olumlu bir niteliği vurgularken daha çok evliyken asker olmanın zorluklarına dikkat çekmişlerdir. Bu zorluklar, eş ve varsa çocuğun özlenmesi ve onların merak edilmesi, maddi-manevi olarak zorluk yaşanıp yaşanılmadığına yönelik endişelerdir. Bu gerekçeler ile askerlik yaparken kaçan ve kaçmayı düşünen katılımcılar olmuştur. Kadın katılımcılar açısından da erkeklerin askerlik yaptıktan sonra evliliklerini gerçekleştirmeleri önemli görülmüştür. Kadın katılımcılar askerliği erkeklerin olgunluk kazandığı bir dönem olarak görmüşlerdir. Bunun yanı sıra, özlem başta olmak üzere yaşanan maddi- 
manevi zorluklara da dikkat çekmişlerdir.

Erkekler açısından özellikle askerliğin evlilikte bir kriter olarak algılanmasına rağmen evliliklerin erken yaşta gerçekleştirilmesi arasında bir çelişki olduğu görülmüş ve erken evliliklerin nedenleri sorgulanmıştır. Erkek ve kadın katılımcılar erken evliliklere yönelik benzer nedenler belirtmişlerdir. Aile ve geleneklere yönelik vurgular ağırlıklı olurken eğitim ve ekonomik faktörler de belirleyici görünmüştür. Bu bağlamda ailenin isteği, erken çocuk sahibi olunması gerektiği düşüncesi, soyun sürdürülmesi arzusu, aileden kopuk bir hayat tarzı, sevgi, eğitimsizlik, aile kararı/aile baskısı, aile yapısının kalabalık olması (çok kardeşlilik, geniş aile yapısı), ekonomik açıdan ailenin durumunun yetersiz olması ve başlık parası geleneği, berdel geleneği, kan davasının son bulacağı düşüncesi, geleneksel açıdan erken evliliğin özendirilmesi ve özellikle kız çocuklarına yönelik evde kalmışlık damgası ve namus gibi olgular erken evliliklerin nedenleri olarak belirtilmiștir. Kadın katılımcılar, erkek katılımcılardan ziyade namus, evde kalmışlık gibi geleneksel nedenler ile ailenin ekonomik açıdan yetersizliğini daha çok vurgulamışlardır.

E7: "Ĕ̆er aileleri kız çocuklarını evlendiriyorsa bu ailelerin kararıdır, ailenin baskısıdır. Ama bence erken evliliğin olmasının nedeni sevgidir. Severek allyorlar birbirlerini o yaşlarda".

E8: "Aile baskısı bence. Aileler evliliği özendiriyor, baskı yapıyor sana. Bazı ailelerde evde tek erkek çocuk varsa onu ister istemez evlendiriyorlar. Çünkü baba diyor ki benim zürriyetimi, soyumu devam ettirsin. Berdel var, kan davası var. Bunlar da klz alıp veriyorlar kan parasını kapatmak için. Ben bunların hepsine karşıyım”.

K1: "Bizim burada biraz yaşı geçince evde kalmış diyorlar. Yani evde kalmış diyecekler kimseyle evlenemeyecekler diye aileler erkenden evlendiriyorlar. Daha çabuk tut sorumluluk sahibi alsın diye evlendiriyorlar". K4: "Aile zoruyla, başlık parası için. Kız kaçmasın evlensin de namusumuzu kirletmesin diye evlendiriyorlar".

K7: "Bence eğitim eksikliği. Çünkü toplumumuzda şöyle bir şey var; büyüklere saygı Anadolu'nun, Türk toplumunun gerçekten çok güzel bir örneğidir. Ama "Küçük yaşta gelin al, bilmiş olmasin.", "Küçük yaşta gelin al, ezebilesin.”, “Sözünü geçirirsin.”, "Küçük yaşta al, çok çocuk doğursun." Bunlardır yani en büyük etkenler".

Yukarıda belirtilenlerden hareketle erken evliliğin nedenlerinin sosyo-kültürel yapı çerçevesinde açıklandığı söylenebilmektedir. Bu yüzden de eşin, ailenin, akrabaların, arkadaşların, çevrenin ve dini söylemlerin erken evlilikler üzerindeki etkisi ve erken evliliklere yönelik bakış açısı ayrıntılı olarak irdelenmeye çalışılmış, böylelikle sosyo-kültürel yapı daha net anlamlandırılmak istenmiştir. Öncelikle eşin erken evliliklere yönelik bakış açısına bakıldığında, katılımcıların eşlerinin erken evliliğe karşı oldukları görülmüştür. Bunun nedeni, erken evlilik deneyimi ile yaşanan pişmanlıktır. Yine de eşlerinin kendi evliliklerini olumlu olarak değerlendirmelerine rağmen genel olarak "erken evlilik" olgusuna karşı çıktıklarını belirten katılımcılar da olmuştur. Özellikle görücü usulü evliliklerde kadının ikincil konumu ve söz hakkının olmaması nedeniyle gerçekleşen erken evliliklerde edinilen tecrübeler erken evliliğe karşı çıkılmasına sebebiyet vermektedir.

E1: "Erken evliliğe eşim de karşı. O zamanlar için konuşuyorum, kadına söz hakk yoktu. Eşimin ailesi karar vermiş, benim ailem karar vermiş, ne diyelim aile baskısı mı, aile korkusu mu ne bileyim. Hani ben nişanlandiktan sonra gittim gördüm. Eşim beni beğenmiş herhalde artık 
yapacak pek bir şey yoktu evlendik öyle”.

E8: "Eşim de pişman, benim gibi düşünüyor o da. Erken evliliği yük olarak görüyor. Bazen diyor yani şimdiki aklım olsa bu yaşımda evlenirdim, daha küçük evlenmezdim”.

Erken evliliğe 1lımlı yaklaşan eşlerin bile zaman içerisinde fikirlerinin değiştiği ve şu anda erken evliliğe karşı çıktıkları görülmüştür. $\mathrm{Bu}$ da erken evlilik deneyimi ve çocukluğun, gençliğin yaşanamaması ile bağlantılı olmaktadır.

K5: "Eşim o zaman iyi baklyordu. Şimdi bakış açısı değişti, benden sonra değişti. Mesela ilk evlendiğimde benim kızım okumaz 15 yaşına geldiğinde evlenir diyordu ama şimdi değişti fikri. Şu an erken evliliğe çok karşı”.

Katılımcıların eşleri arasında erken evliliğe 1lımlı yaklaşanlar da bulunmaktadır. Erken evliliğe 1lımlı yaklaşılması, evlilik yaşına önem verilmemesine bağlanmıştır. $\mathrm{Bu}$ da erken evliliğin meşrulaştırıldı̆̆ını göstermektedir.

K4: "Bilmiyorum da yani eşim nişanlıydı, nişanı atıp sonra gelip beni istemişler. Ona göre erken evlilik diye bir şey yok vakti gelen evlenir”.

Sosyo-kültürel açıdan önemli diğer bir faktör de ailedir. Bindik’in (2012) yaptığı bir çalışmada geleneksel ve otoriter aile yapısının, dini inanışların, geleneksel değerler ve ilişkilerin erken evlilikte etkili olduğu ifade edilmiştir. Çalışma kapsamında ele alındığında ise katılımcılara göre ailelerinin erken evliliğe yönelik bakış açısı da kişilerin evliliklerini gerçekleştirmelerinde belirleyici olabilmektedir. Araştırma kapsamında katılımcılara göre aileler erken evliliği normal kabul etmekte ve evliliğin erken yapılmadığını düşünmektedirler. Bunun nedeni erken evliliklerin sosyo-kültürel açıdan meşrulaştırılmış olmasıdır. Dolayısıyla aile aracılığıyla da bu meşruluk sürdürülmektedir.

E5: “Ailem erken evliliğe karşı değil, hatta onlara göre bu durum erken evlilik olarak bile görünmüyor. O zamanlar öyleydi, öyle evleniliyordu. Kardeşlerim de öyle evlendiler"

K8: "Ailem zaten erken evlilik olarak görseydi beni vermezlerdi. Ailem fakirdi, biz çok kardeştik beni de o yüzden verdiler. Bana ailem bakamıyordu evlenip gidelim de yük kalksın diyorlard, yani ben onlara yüktüm”.

Bazı katılımcıların eşlerinde olduğu gibi ailelerinde de erken evliliğe yönelik bir bilinçlenme olduğu belirtilmiştir. Katılımcılar, ailelerinin eskiden erken evliliğe ılımlı yaklaştıklarını ancak artık karşı olduklarını belirtmişlerdir. Bu düşünce değişiminin nedeni de erken evlilik deneyimiyle yaşanan pişmanlıkla açıklanmıştır.

K6: "O zamanki kafayla doğru buluyorlardl. Ama şimdi çok pişman, doğru bulmuyor. Bana diyor "Kızım hakkını helal et, ben seni zorla verdim, çok pişmanım” diyor.

Katılımcılara göre akrabalarının erken evliliğe yönelik bakış açıları ele alındığında ise akrabalar ile ailelerinin düşüncelerinin paralellik gösterdiği görülmüştür. Buna göre, akrabalar erken evliliğe 1 lımlı yaklaşırken beşik kertmesi gibi evlilik türlerine karşı çıkmaktadırlar. Diğer yandan, bazı katılımcıların akrabalarında da zaman içerisinde bir düşünce değişimi olduğu ve erken evliliğe artık karşı çıktıkları bulgusu elde edilmiştir. Bu değişim, ailede olduğu gibi erken evlilik deneyimi ile açıklanmıştır. 
E1: "Akrabalar da olumlu görüyor. Tabi erken evlenmeme karşı değiller beşik kertmesi olayına karşılar".

K8: "Akrabalarım onlar şimdi kendi çocuklarını o yaşlarda evlendirmezler. Onlardan da erken yaşta hani evlenenler olduğu için kendi çocuklarını o yaşlarda evlendirmeye karşı çıkarlar”.

Katılımcılara göre arkadaşları ve çevrelerindeki kişilerin erken evliliğe yönelik bakış açılarında ise erken evliliğe karşı olma hali hakimdir. Bunun nedeni de aile ve akrabalarda olduğu gibi, erken evlilik deneyimine bağlı olarak görülen pişmanlık duygusudur. Bilinçlenmenin diğer bir nedeni ise kitle iletişim araçları ve eğitim seviyesinin yükselmesi olarak belirtilmiştir.

E5: "Arkadaşlarım ve çevrem farklı düşünüyorlar arkadaşlarım da erken evlilik yapanlar olduğu için hepsi pişmanlar ve karşılar ama çevrede bu durum normal karşılanıyor".

E8: "Arkadaşlarım ve çevrem önceleri olumlu baklyorlard. Ama zaman değişti, teknoloji çıktı. Televizyonlarda, internette, haberlerde anlatıllyor bu evliliği ne kadar kötü olduğunu. O yüzden artık onlar da karşılar bu duruma".

K8: "Artık öyle bir devir gelmiş ki kimse çocuğunu o yaşlarda evlendirmiyor. Çünkü artık herkes çocuğunu okutuyor. Ama okutmayanlar yani böyle, köyde klyıda köşede kalan aileler tek, çocuklarını o yaşlarda evlendiriyor o da cehaletten kaynakl bence. Dediğim gibi bu devirde kimse öyle küçük yaşlarda evlenmiyor".

$\mathrm{Bu}$ bilinçlenme durumunun aksine, bazı katılımcılar da çevrelerinde hâlâ erken evliliklerin devam ettiğini ve kadınların ikincil konumda olduklarını belirtmişlerdir. Evlilik gerçekleştirilirken kadınların düşüncelerinin önemli olmaması, kadınların evlenecekleri kişiyi seçememeleri, kadınlara yönelik namus algısı ve başlık parası erken evliliklerin hâlâ gerçekleşmesine sebebiyet veren nedenlerdir. Aydın ve Akay'ın $(2017,42)$ yaptıkları çalışmada da eğitimin yetersiz olması, kültürel faktörler ve kız çocuklarının toplumdaki yeri erken yaşta evliliğin en önemli nedenleri arasında yer almaktadır.

K5: "Çevrem hepsi erken evlilik zaten bu yüzden olumlu bakiyorlar. Sebep cahillik. Şimdi öyle bir dönem gelmiş ki kizlar rahat durmuyor, babalar korkuyor başımızı önümüze eğecekler diye. Bizim dönemimizde evlensin evinin kadını olsun diyorlardı ama şimdi öyle değil aman evlensin başımızı yere eğdirmesin diyorlar. Çoğu böyle düşünüyor. Çoğu da başlık parası için evlendiriyorlar".

Eş, aile, akrabalar, arkadaşlar ve çevredeki kişilerin yanı sıra sosyo-kültürel açıdan üzerinde önemle durulması gereken diğer bir faktör de dindir. Erken evlilikler din ile de meşru kılınmaktadır. Böylelikle kişilerin erken evliliği kabul etmeleri sağlanmaya çalışılmaktadır. Evlilikler din bağlamında "kader, kısmet, nasip" kavramlarıyla açıklanmaktadır.

K7: "Zaten hep bunlar kullanllir yani erken evliliklerde birinin istemedig $i$ durumlarda direk din devreye girer ve din ile insanları bastırmaya çalışılar. "Nasibinde bu var, kaderinde bu var, senin kaderinmiş bu asla değişmez, hakkinda hayırlısı buymuş, sen orada ăglamaktan ölsen de nasibinde bu varmış" deyip de bizi sustururlardl. Zaten bizim toplumda din her zaman gelenek görenek dinin üstündedir istedikleri zaman istedikleri konuda dini çok rahat kullanabilirler”. 
Sosyo-kültürel açıdan olumlanan ya da bilinçlenmenin sağlanmasıyla karşı çıkılan erken evlilikler katılımcılar tarafından olumlu ve olumsuz sonuçlarıyla da değerlendirilmiştir. İlk olarak erken evliliklerin olumlu sonuçlarına bakılırsa, sahip olunan çocuklar ile arada yaş farkının az olması, çocuklarla arkadaş gibi olmak ve çocuklarla birlikte büyümek gibi hususlara yer verildiği görülmüş̧ür. Erken evliliklerin olumsuz sonuçlarına bakıldığında ise erken yaşta evlenme nedeniyle çocukluğun, gençliğin yaşanamaması, tecrübesizlik, evlilik ile birlikte çocuk yaşta belirli sorumlulukların altına girilmesi, şiddet, fiziksel ve psikolojik bozukluklar, geçimsizlik ve çatışmalar, çocukların bilinçli bir şekilde büyütülememesi gibi hususlara ver verildiği görülmüştür.

E2: "Olumlu sonucu çocuklarmla beraber büyüdüm. Onlarla arkadaş gibiyim. Ama olumsuz çok sonucu oldu. Biz sürekli kavga ederdik çocuklarımın psikolojisi bozuldu. Ben de karım da çocukluğunu yaşayamadı. Gözümüzü bir açtrk çocuğumuz olmuş, çocuk yaşta çocuk büyüttük. Evliliği hep bir pişmanlık olarak gördüm. Karım beni hiç sevmedi, ona çok eziyet ettim. Bu yüzden bana hep bir pişmanlık oldu”.

K1: "Olumsuz şeyler oldu. Çoğunlukla dı̧sarıdan yardım altyorsun, diyorsun acaba bunu yapsam yanlış mı olur, bunu yapsam doğru mu olur. Kendi kararın kendin veremiyorsun, vermek istiyorsun ama birileri seni yönlendiriyor yaşın küçük olduğu için. Küçüksün eşine nasıl davranacaksin bilmiyorsun, nasil bir hayat kuracaksin bilmiyorsun".

K8: "Valla bende iyi sonucu olmadl. Kocam hep döverdi o yüzden kafamda kalıcı hasarlar oluştu. Çocuklarımla arkadaş gibi büyüdüm onlara tam annelik yapamadım bunun vicdan azabını yaşlyorum her Allah'ın günü’.

Bunların yanı sıra, evlenilen kişilerin yaşlarının büyük olması ya da arada yaş farkı olması da evlilik içerisinde olumsuz durumlar yaratabilmektedir. Ancak bu durum özellikle de kadın eşin erkek eşten büyük olması ile gerçekleşmektedir. Bu da kültürel açıdan evliliklerde kadının yaşının erkekten büyük olmaması gerektiğini göstermektedir. Erkeğin yaşının kadının yaşından büyük olduğu durumlarda kültürel açıdan bir sorun yaratılmadığı görülmüştür.

E4: "Bana göre ailemde erken evliliğimde olumsuzluk yaşamadım. Sadece çevremdekilerin karımın yaşından büyük oluşuna takılmaları, bana bu konuda baskı yapmaları, sıkıntılıydı. Yani yaş farkından dolayı rahatsızlık duydum. O da çevremden dolayıydı".

Kısacası, erken evlilikler sadece çocuklar ile arada yaş farkının az olması açısından olumlu olarak değerlendirilmiş, erken evliliklerin olumsuz sonuçlarına yönelik daha çok vurgu yapılmıştır. Erken evliliklerin başlıca olumsuz sonuçları ise çocuk yaşta evlilik sorumluluğunun alınması, çocuk yaşta annelik-babalık deneyimleri, yaş farkları, geçimsizlik, şiddet, fiziksel ve psikolojik sorunlar olarak belirtilmiştir.

\section{Evlilik Yaşantısı}

Araştırmada, evlilik yaşantısı konusunda evlilik kararı, evlenme şekli, evlenme nedeni, evlilikte yaşanılan zorluklar ve kimlerle birlikte yaşandığı, eş olarak beklentilerin neler olduğu gibi hususlara değinilmektedir. Bunlar içerisinde ilk olarak evlilik kararının nasıl alınmasıyla ilgili katılımcıların düşüncelerine bakıldığında kadın katılımcılar ile erkek katılımcıların evlilik kararına yönelik görüşlerinin benzer olduğu görülmüştür. Buna göre, evlilik kararının çiftler tarafından alınması gerektiği vurgulanmış, evlilik kararının evliliğe yönelik bilincin oluştuğu bir yaşta ve bu bilinçle alınması gerektiği belirtilmiştir. Buradan da katılımcıların erken evlilikle 
birlikte evlilik yaşantısı ve çocuk bakımı konusunda bilinçsiz oldukları anlaşılmaktadır. Diğer yandan, geleneksel olarak varlığını sürdüren görücü usulü, berdel gibi evliliklere karşı çıkılmış ve bu evlilikler sürecekse bile evlenecek olan kişilerin kararının önemsenmesi gerektiğ vurgulanmıştır.

E1: "Evlilik kararını bence, ben buranın şartları için söylüyorum, görücü usulü olsa bile kesinlikle çiftler almalıdır. Zaten hayat onların hayatı. Sonuçta bu iş karşıllklı rızayla olabilecek bir iştir. Kimsenin müdahale etmemesi lazım. Yani aileler destek çıkmall, anlayış göstermeli, eşler de anlaşmall, uyumlu olmalıdır. Yani ben çocuklar gezsinler, tozsunlar, sevgili olsun ona da karşıyım. Görücü usulü olsa da eşler birbirini önceden görmeli ve anlaşmalıdır. Bu onların vereceği karardır”.

E6: "Evliliğin ne olduğunu bildikten sonra o karar alınmalıdır. Yani kart-kocanın ne demek olduğunu, çocuk sahibi olduğunda ne yapman gerektiğini, o çocukların nasıl yetiştirileceğini, o çocukların ahlaki olarak nasl olması gerektiğinin bilincindeyse evlenebilir. Bu kararı evlenen çiftin kendisi alması lazımdır. Birbirlerine uygun olup olmadıklarını konuşmalarl gerekir".

Evlilik kararı verilmesinde evlenecek olan kişilerin kendilerinin karar vermesinin yanı sıra burada çiftlere ailelerinin desteği ve ailelerin uzlaşmaları da önemsenmiştir. Bu da aile rızasının alınmak istendiğinin bir göstergesidir.

K3: "Her iki taraf da ortak almalıdır. Tek taraflı karar alınmamalıdır. Sonuçta ailelerden ziyade ikisi birlikte hayat sürdürecekler. Bu kararı da onlar almalıdır. Ailelerin fikri de önemli, ama gençlerin fikri daha önemli bence".

Katılımcıların evlenme şekillerine bakıldığında ise kadın katılımcıların üçünün görücü usulü, üçünün aile isteği, birinin akraba isteği ve birinin de severek ve ailenin maddi durumunun yetersizliği nedeniyle evlendiği görülmüştür. Dolayısıyla sekiz kadın katılımcının yedisinin kendi tercihleri ve istekleri doğrultusunda aşk evlilikleri yapmadıkları söylenebilmektedir. Erkek katılımcılarda ise kadın katılımcılarda belirtilen görücü usulü evlilikler mevcut olmamakla birlikte katılımcılardan biri beşik kertmesi, ikisi aile isteği ile evlenirken geriye kalan beş katılımcı ise aşk evliliği gerçekleştirmişlerdir. Aşk evliliği yapan katılımcılar da kendi içlerinde farklılaşırken evliliklerin bir kısmının kaçarak, bir kısmının aile tavsiyesi ve bir kısmının da başlık parası ile gerçekleştiği görülmüştür. Bunlardan yola çıkılarak araştırmada yer alan katılımcıların farklı şekillerde evlendikleri söylenebilmektedir. Katılımcıların evlenme nedenleri de evliliklerini gerçekleştirme şekilleriyle paralellik göstermiştir. Buna göre, araştırmaya katılan katılımcıların evlenme nedenleri beşik kertmesi, aile zoru, maddiyat, sevgi, kaçma, görücü usulü ve aile isteği olarak belirtilmiştir. Sevgi dışındaki nedenlerle gerçekleşen evliliklerde kişilerin eşlerini kendilerinin seçmemiş olması göze çarpmaktadır. Eşin seçilememesinin yanı sıra, evlilik bir dayatma şeklinde gerçekleşmiş ve evlilik kişiler açısından "oldu bitti"ye getirilmiştir. Bu da evliliğin anlamlandırılamaması demektir.

E1: "Benim evliliğim beşik kertmesi. Ben nişanlandıktan sonra nişanlımı gördüm. Görücü usulü değildi evliliğim. Daha önce hiç eşimi görmemiştim. Küçükken bir kere evimize gelmişti. O zaman hayal meyal hatırlıyorum onu. Ondan sonra hiç görmedim, hiç köye de gitmedim. Evleri köydeydi zaten. Aradan yıllar geçti işte. Ben İstanbul'da çalışlyordum, işçiydim orda. Benim amcamın oğlu, o zaman ankesörlü telefonla beni 
aradl ve bana dedi "Seni evlendirmişler" Bana o haberi o verdi". K7: "Zoraki bir evlilikti, 13 yaşındaydım 1993 yllının ocak 1 tarihinde, gece saat 3 gibiydi, kalabalıkt ev. Anneme sordum bana söylemedi. Tabii aşiret büyükleri filan toplanmış annem beni uyuttu bir şey söylemedi. Gece beni tekrar uyandırdılar, başıma bir kırmızı örtü taktılar, işte parmağıma yüzük taktılar, başımda birileri alkışladı, birileri bana elini öptürdü, birileri bana gelinimsin dedi, kimin geliniyim, kiminle evleniyorum çözemedim. Böyle bir ilk şaşırdı. Sonra dediler işte seni şuna şuna verdik. Eski eşim diyeyim benden 11 yaş büyüktü ve ben ona abi diyordum. Abi olarak çok seviyordum. Bizim akrabaydı yani abimle evlenmişim gibi hissettim çok berbat bir durumdu, kabullenemedim”.

Evlilik gerçekleşirken gelinlik veya damatlık giyilip giyilmediğine bakıldığında ise araştırmaya katılan tüm erkek katılımcılar damatlık, tüm kadın katılımcılar ise gelinlik giymişlerdir. Ancak damatlık veya gelinlik giyinmek, onlar için birer giysiden ziyade farklı anlamlar taşımaktadır. Kimisi için damatlık veya gelinlik önemsiz görülürken kimisi için ise önemli olarak görülmüştür. Damatlık veya gelinlik giymenin geride kalan gençliği, hayalleri, şu an için bir pişmanlığı, örf ve adetleri, namusu ve ölümü temsil ettiği belirtilirken diğer yandan da hatırası olan özel bir günü ifade ettiği belirtilmiştir.

\begin{abstract}
E1: “Tabii damatlı giydim. Düğün gereği damatlı giymek adettendir. $O$ zamanlar da öyleydi, şimdi de öyle. Bir insan evlendiği zaman yani onun yerine kefen de giyse mutlu olmaya çalışır. Ama ben gerçekten evlenmeye razı değildim, mutlu da değildim. Bu 3-4 senedir fikrim değişti tabii. Çünkü yapacak bir şey yok onu öğrendim gerçekten. Sevdiğim bir insan vardl. O hâlâ bekar. Ama ben şimdi onunla evlenemem. Eşimden ayrılamam. Buna yaşadı̆̆ım çevre de, toplum da karşı çıkar. Yani gençken yaşadın yaşadın, yaşamadıysan kalıyor her şey”.

K8: "Evet giydim. Yani gelinlik o zamanlar benim için anlamsızdl. Ben hep çevremde evlenen gelin ablaları görmüşken, birden ben gelin oldum ve kendimi o elbisenin içinde buldum. Sözde severek evlendim ama evlilik ne onu bile bilmiyordum. Şimdilerde bana sorsanı gelinliğin anlamı nedir diye, size sadece gelinlik kefendir derim. O beyazlı̆̆ın anlamı sonsuzluk, saflıktır. Yani demem o ki sonsuzluk ölümü ifade eder o yüzden kefen olur, saflık da namusu simgeler hani ne bileyim işte daha kızdır, bekardır anlamını taşır. Bana göre önemlidir tabii”.
\end{abstract}

Erken evlilikle birlikte kişilerin evliliklerini nasıl gerçekleştirdikleri de önemli bir konu olmaktadır. Buna göre, araştırmada yer alan kadın ve erkek katılımcıların önce dini nikâh sonrasında ise resmi nikâh yaptıkları görülmüştür. Katılımcılar içerisinde erken evlilik gerçekleştirdiği eşiyle sadece dini nikâh yapan iki katılımcı bulunmaktadır. Bu katılımcılar, kültürel açıdan dini nikâha resmi nikâhtan daha çok önem verildiğini belirtmişlerdir. Sonradan resmi nikâhın yapılma nedenleri arasında ise katılımcıların çocuk sahibi olmaları, kanunen reşit olma şartını sağlamaları ve ebeveyn imzasıyla evlenmenin sağlanabiliyor olması olarak belirtilmiştir. Belirtilen bu gerekçeler içerisinde özellikle çocuk sahibi olma vurgusu dikkat çekmektedir. Çünkü resmi nikâhı olmayan çiftlerin çocukları nüfusa kayıt ettirilememekte dolayısıyla sağlık, eğitim başta olmak üzere devletin çeşitli hizmetlerinden yararlanmakta sıkıntılar yaşamaktadırlar. Dolayısıyla resmi nikâh çocuk sahipliği noktasında resmi işlemlerin yapılabilmesi ve kamu hizmetlerinden yararlanılabilmesi açısından önemli görülmüştür. 
E5: "Ya aslında hiç resmi nikâhımız olmadı. Sadece dini nikâh kıydık. Tabii yine bizim buralarda resmiyete önem vermiyorlar. Sadece çocuk olduğu zaman resmi nikâh yapllyyor, çocuk resmiyette gözüksün diye. Ama tabii ikinci evliliğimde resmi nikâhım vardl, çocuğum da vardı".

K4: "Dini nikâh kıyıldı. Resmi nikâhımız hâlâ yok. Çünkü eşimin kimliği yok. Hiç kimliği olmamış. Doğduğundan beri hiç kimlik çıkartmamışlar. Çünkü eşimin anne babası kimlik çıkartmamışlar, onların da resmi nikâhr yok. Ne okula göndermişler, ne hastaneye gidebiliyor ne de bir yere gidebiliyor. Hastaneye giderken akrabaların kimliğini alıyor. Ama ŭgraşlyoruz kimlik çıkartacağız inşallah”.

Katılımcılar içerisinde önce resmi nikâh ardından da dini nikâh yapan bir katılımcı da bulunmaktadır. Özellikle katılımıının bir yıl ardından resmi nikâh yapması ve bu sürede dini nikâhlarının da olmaması, evlilik dışı bir yaşamın varlığını da gösterir niteliktedir. Son olarak bir katılımcı da aile vekaletiyle dini ve resmi nikâhın birlikte yapıldığını belirtmiştir. Bu durum ise kanunen erken evliliklerin yolunun açık olduğunu ve aile vekaleti, aile izni gibi çeşitli yollarla erken evliliklerin gerçekleştirilebildiğini göstermektedir.

Evlilik belirtilen şekillerde gerçekleştirilmiş olsa da evlilik sonrasında aile yaşamı içerisinde çeşitli zorluklar da yaşanmıştır. Bu zorluklar içerisinde öncelikle yoksulluk belirtilebilir. Yoksulluk, maddi olanakların yetersizliğine bağlı olarak eşin evlilik sonrası askere gitmesiyle yaşanılan maddi zorluklarla da açıklanmıştır. Diğer bir zorluk ise erken yaşta evlenme nedeniyle kişilerin kendilerini özellikle evliliğin ilk yıllarında çocuk hissetmeleri nedeniyle evlilik ve eşe karşı sorumluluklarını yerine getirebilme noktasında yaşanmış olup bu zorluk çocuk bakımı ve annelik-babalık rollerinde kendisini göstermiştir. Özellikle görücü usulü ve berdel evliliklerde eşlerin birbirlerine karşı ilgisizlikleri, şiddete kadar uzanan geçimsizlikleri ve aldatma aile yaşamı içerisinde yaşanan diğer bir zorluklardır. Eşin ailesi ile birlikte yaşanması durumda ise kadın katılımcıların özgürlüklerinin kısıtlanması ve aileleriyle görüştürülmemesi gibi zorlukların da yaşandığı görülmüştür.

E2: "Illk evlendiğim yıllar çok zorluk yaşadım. Çobanlık yapıyordum. Evliydim eve geliyordum, oturuyordum televizyonun başında çizgi film izliyordum. Sonra kafayı vurup yatıyordum. Bir yıl böyle gitti. Biz karlkoca olmak nedir bilmiyorduk. Büyükler anlatıyordu ama çocukluk işte anlamıyorduk. Bir yıl bizim hiç çocuğumuz olmadı. Çünkü eşime yaklaşmıyordum. Cahildim, bilmiyordum. Bir yıldan sonra yavaş yavaş büyüklerin de baskısıyla bir çocuğumuz oldu. Ama çok zorluk çektik. Bebek büyütmeyi bilmiyorduk. Anne olmayı bilmiyordu eşim. Ben babalık zaten yapamıyordum. Maddi anlamda da zorlandık. Çünkü ailemin zaten durumu belliydi. Ben çobandım. Çok zordu bir evi geçindirmek. Aldığım parayı babama verirdim, babam bize bakardı".

K8: "Yaşadım ama öyle kaynanamla felan değil. Kocamla çok sorun yaşadım. Yeni evliydik yani hani ilk evlendiğinde eşin sana her konuda destek olur ya işte bizde öyle olmadl. Kocam her firsatta beni ezdi, hor gördü. Onun benden bekledikleri farkliydı. Benden tam kadın olmamı istiyordu, ne bileyim işte cilveli olsun, kocasının sözünde olsun, yemek yapsın, evi temizlesin felan işte öyle şeyler. Ben de bunların hepsini aynı anda yapamıyordum. Bu yüzden sürekli kavga ediyorduk. Ben çocuktum nasıl davranmam gerektiğini bilmiyordum. Ailesi beni nasll yönlendirse öyle davranıyordum. Biz maddi sikıntı da çok yaşadık. Kocam esnaftı. 


\section{Küçükken babasının yanında çalışıordu. Biz hep kayınpederimin eline baktık. Onun verdikleriyle yetindik. Çok zorlandık, parasız çok kaldık yani”.}

Erken evlilikle birlikte aile içerisinde yaşanan diğer bir zorluk ise eğitimdir. Bu süreçte özellikle kadınların eğitime devam etmelerine sıcak bakılmamaktadır. Bu durum eğitimin yarıda kalmasına neden olabilmektedir. Katılımcının ifadelerinde de bu durum görülmekle birlikte bazı katılımcılar açısından "okuma isteği”"nin sadece dini kitaplarla sınırlandırılmaya çalışılması dinin sosyo-kültürel açıdan baskın rolünü de göstermektedir.

K7: "Evet çok zorluk yaşadım. Ekonomide de oldu, eğitimde de oldu. Çünkü beni okutmadılar. 6. sınıfta çıkardılar zoraki. Ben okumak istiyordum, evlenmek değil. O yüzden eğitimim yarıda kaldı. Rüyalarımda okula gittiğimi görüp ağlardım. Böyle yani evlendikten sonra da kitap okumama karışıp "Terbiyesiz şeyler okuyorsun” derdi. Halbuki okuduğum dünya klasikleri ve romanlardı. Hatta hiç unutmuyorum 'Sefiller' kitabını okurken kaynanam elimdeki kitabı alıp yere firlatmıştı. Bana kızmıştı 'Sefiller'i okuyacağına git Kuran-ı Kerim oku, terbiyesiz!' demistit”.

Araştırma alanımıza yakın sosyo-kültürel özelliklere sahip olan Diyarbakır'ın Bismil ilçesinde erken evliliklerle ilgili yapılan çalışmada benzer sonuçlara rastlanılmaktadır. Bu araştırmada da yoksulluk, eğitim seviyesinin düşük olması, istihdam problemi ve çocuk sayısının fazla olması erken yaş evliliğin ve çocuk sahipliğinin önemli nedenleri olarak tespit edilmiştir. Ayrıca erken evlilikler ve erken yaşta çocuk sahibi olmasının kişilerin yaşadıkları yerin sosyo-kültürel yapısından, eğitim seviyesinin düşük olmasından ve ekonomik nedenlerden kaynaklandığı ileri sürülmüş̧ür (Orçan \& Kar 2008, 109-110).

Araştırmada yer alan katılımcıların evlilik sonrası kimlerle yaşadıklarına bakıldığında katılımcıların erkeğin ailesiyle birlikte yaşadıkları görülmüştür. Bu katılımcılar içerisinde iki katılımcı daha sonra eşleriyle ayrı eve çıtıklarını belirtmişlerdir. Katılımcılara göre, aileyle birlikte yaşamanın hem olumlu hem de olumsuz yanları bulunmaktadır. Aileyle yaşamanın olumlu yanı, aile içerisinde kişilerin birbirlerine maddi olarak destek olmaları, aile büyüklerinin yol gösterici olması ve aileye bakımın üstlenilmesi noktasında toplumsal açıdan saygı görülmesi olarak belirtilmiştir. Burada göze çarpan nokta, sosyo-kültürel açıdan ailede en küçük ya da en büyük erkek çocuğun aileyle birlikte yaşayarak ailenin bakımını ve ihtiyaçlarını karşılaması yönünde bir beklentinin olmasıdır. Ancak belirtilen bu olumlu nitelikler, aynı zamanda olumsuz nitelikleri de içerisinde barındırmaktadır. Çünkü evli kişilerin ebeveynlerinin ve ailede birlikte yaşamlarını sürdürdükleri diğer kişilerin yanlarında özgürlükleri ve mahremiyet alanları kısıtlanmaktadır. Kendileri tam bir aile olamamakta "evlilik" noktasında tam bir bilinçliliğe ulaşamamaktadırlar. Bu ise ailenin her konuda desteğinin olması, kişilerin maddi-manevi zorluklarla karşılaşmamış olmaları ve eşle tam olarak birlikte zaman geçirilememesiyle açıklanmıştır. Aile yanında eşle ilgileniyor olmak ya da çocuğunu sevmek ise "ayıp" olarak algılandığ için eş ve çocuğa yönelik ilgisizlik de doğmuştur. Bu durum sadece eşlerin birbirlerine karşı ya da çocuğa karşı ilgisizlikle sınırlı değildir. Aynı zamanda hem kadın katılımcıların hem de erkek katılımcıların eşlerinin aileleriyle görüşmelerinin kısıtlanması noktasında aileye yönelik bir ilgisizlik de söz konusudur. Bu kısıtlanma sadece aileyle görüşme noktasında kalmamış, kadınların tüm hayatlarını çevrelemiştir. Benzer şekilde Tan-Eren'in (2017, 170-173) erken evliliklerle ilgili Ardahan'da yaptığ 1 bir çalışmada da erken evlilik gerçekleştirerek evlenen çiftlerin ebeveynlerle birlikte yaşamaları sonucunda birçok sıkıntı yaşadıkları görülmüştür. 
E2: “...Yok ayrı ev yoktu, yine annem, baba, karımla ve çocuklarımla yaşıyordum. Çünkü ben evin küçüğ̈̈ydüm o yüzden anne babama bakmak benim görevimdi. Valla sikıntısı da oldu, faydası da oldu. Bir kere büyüklerin senin yanında sana yol gösteriyor hep. O zamanlar çocuksun bilmiyorsun evlilik nedir. Annem karıma kızı gibi bakıyordu, her şeyi öğretiyordu. Ama sıkıntısı da oldu da aynı evdesin sonuçta. Babanların yanında karına seslenemiyorsun. Çocuğunu kucă̆ına alamazsin. Çünkü burada çocuğunu babanın yanında ya da bir büyüğ̈̈nün yanındayken kucağına alsan ayıp olur. Evde babam baklyordu bize. $O$ zamanlar ben küçüktüm çobanlık yapıyordum. Vallahi eşinle duygusal bir şey yaşayamiyorsun. Çünkü annen, baban evde. Karım için de zordu. Hâlâ zor. Babam bizimle halen. Ama bir yandan da iyidir, sonuçta tecrübelidir. O kavgalarımızda sıkıntılarımızda bize hep yol gösterdi”.

E3: “...Yok ayrı ev açmadım. Annem, babamla kaldık. Hâlâ da annemle kallyoruz. Babam geçen yll vefat etti... Çok faydası var. Çünkü ailem bize yol gösterirdi. Şöyle yapsan daha iyi, böyle yapsan daha iyi filan derdi. Zor yanı da var. Daha çabuk çoluk çocuk sahibi oluyorsunuz. Kendi kazandiğın parayı daha çok sahiplenebiliyorsun. Toplumda sana saygı duyuyorlar. Sonuçta çoluk çocuk babasısın. Sana saygı duyuyorlar".

K5: "Eșim ve çocuklarımla. Yok. Eșim, kayınpederim, kaynanam ve kayınımla yaşlyorduk... Sikıntılar oldu. Eşinle diyalog kuramıyorsun. Eşimin ailesiyle problem yaşlyordum. Sosyal hayatım yoktu. Onlarla 6 yıl yaşadım ve 6 sene boyunca hiç dışarı çıkamadım. Onlar bırakmadılar beni eve hapsettiler. Eşimle tartıştı̆̆ımda onun ailesine yansiyordu tartışmamız. Ben eşimle tartıştı̆̆ımda ailesi de benimle tartışıyordu. Rahat değildim".

Erken evliliklerde ilk olarak aileden ayrı, eşle yaşandığı da görülmüştür. Ancak burada dikkat çeken durum, erken yaşta evlilik bilincinde olunamaması ve evlilik hayatına ilişkin zorluklar yaşanmasıdır. Bu da eşler arasında çatışmaları doğurmuş ve çatışmaların yaşanmasından dolayı bir katılımcı aileyle birlikte yaşamak zorunda kaldığını belirtmiştir. Aileyle birlikte bu bilincin kişilere verileceği düşüncesi ve ailenin "yol gösterici” niteliği burada etkili olmuştur.

K3: "Çocuklarımla, iki kızımla yaşıyorum şu an... Ilk ayrı eve çıktık. Anlaşamadık, büyük tartışmalar oldu yani. Sonra kayınpederim karar verdi. Dedi ki küçüktürler anlaşamıyorlar onları eve alalım. Tekrar evin içine geri girdik... Maddi bir sıkıntı yaşamadık. Sadece eşimin kıskançlıkları vardl. İlla baskı vardı üzerimde. Ailene gidemiyorsun, ailen gelemiyor o konuda çok baskı oldu öyle. O konuda çok baskı oldu”.

Evliliğin gerçekleşmesiyle eşlerin birbirlerinden beklentileri de değişmektedir. Bu beklentilerin karşılanamaması ya da beklentilerin karşılanmasında bilinçli olmama durumları önceden belirtildiği gibi erken evliliklerde yaşanan zorluklardan biri olmaktadır. Eş olarak kişilerden beklenenler cinsiyete göre değişmektedir. Buna göre, erkeklerden erkeklik rollerini kadınlardan ise kadınlık rollerini gerçekleştirmeleri beklenmektedir. Ancak her iki cinsiyet için de ortak olan nokta, çoğu katılımcı açısından eş olarak beklenen rollerin gerçekleştirilmesinde zorlanılması, çocuk olma ile eş olma rollerinin birbirlerine karıştırılması ve çocukluğun yaşanamamasıdır. Öncelikle erkek katılımcıların eş olarak kendilerinden beklenenlere bakıldığında cinsel rollerini yerine getirmeleri, babalık, evin geçimini sürdürme, ailenin namusunu koruma, eşe karşı so- 
rumluluklarını yerine getirme gibi beklentilerin olduğu görülmektedir.

E1: "Ben ilk başta eşime kocalık yapamıyordum. Yani hep birbirimizi yoruyorduk. Ben ona hep derdim 'Sen niye benimle evlendin?' diye, o da bana derdi, 'Benim ne suçum var, sen istemeseydin beni.' falan diye. Çok şiddetli sıkıntılar oldu aramızda. Mesela hep derdim 'Senden memnun değilim, hayatımı yaşamak istiyorum. Niye benimle evlendin?' diye. Yani benden istenen kocalık davranışları evine, karısına baksin, para getirsin. Ben ilk zamanlar bu kocalık davranışların yerine getiremiyordum, bunlarl yapamiyordum".

E8: "Çallş, eve ekmek getir, çocuğa bez getir. Bir nevi 'Para getir, tamamdır.' gözüyle baklyorlardl. İ̧̧imde hep bir üzüntü kalmıştır. Ben çocukluğumu yaşayamadan çocuk sahibi oldum. Halen de içimde kalmıştır. Uzaktan kumandalı bir arabamın olmasını çok isterdim. Çocuklarıma aldım şu an. Ama benim içimde kaldı. Evliliğimde de bu eş davranışını yapamadım”.

Kadın katılımcılara göre eş olarak kendilerinden beklenenlere bakıldığında ise eşe karşı sorumlulukların yerine getirilmesi, annelik rolü, erkek çocuk sahibi olabilmek, yemek ve temizlik gibi ev içi işlerin gerçekleştirilmesi, eşe karşı sevgi ve saygı, eşe sadık olmak ve eşin dediği her şeyi gerçekleştirmek olarak belirtilmiştir. Burada da katılımcıların eş olarak beklenenleri gerçekleştirmekte ve "oyun" algısından çıkmakta zorlandıkları görülmüştür. Özellikle de kadınlara yönelik beklentiler, kadınların bir "hizmetçi” ya da bir "köle" gibi algılandığını göstermiştir. $\mathrm{Bu}$ ise kadınların sosyo-kültürel yapı içerisindeki ikincil konumunu yansıtmaktadır.

K4: "Eşine iyi davran, saygll davran, eşinin bir dediğini iki etme. Çalışın bir ev kurun. Hamile kaldım, çocuğun kız olduğunu öğrenince kaynanam eşime kızdılar, bana kızdılar. Erkek çocuk olmasını istiyorlardı. Ben 9 ay boyunca hep ağladım. İlk evlendiğimde yapamıyordum eş gibi olamıyordum, cahillik çok vardl, bir şey bilmiyordum. Eş gibi davranmak için elimden geleni yaplyordum".

K7: "Bizim çevremizdeki insanlar için sadece beklenen iyi bir annelik, iyi bir eş, iyi bir gelin, iyi bir hizmetçi, iyi bir köle genelde bunlardır kadından her şey beklenir. Karşılamaya çalıştım. Yaşım 30'a gelince artık isyan etmeye başladım. 30'dan sonra artık okumaya başladım ki okumayı çok seviyorum. Yavaş yavaş artık kullanıldığımı hissetmeye başladım. Sonradan artık kabullenmemeye başladım”.

K8: "Eş gibi davranmak işte cilveli işveli olmak, kocanın sözünü dinlemek, çocuklarına bakmak, eşine evine sağdlk olmaktır. İlk evlendiğimde çocuktum işve cilve nedir bilmezdim. Kocam bana dokunduğunda midem bulanırdı kendimi kötü hissederdim. Yemek yapmayı bilmezdim. Küçükken arkadaşlarımla evcilik oynardım, he ya bilmezdim evciliğin gerçek evlilik olduğunu, bana hep oyun gibi gelirdi ama oyun değildi. Çamurdan pasta yapmaya benzemiyordu bu durum hiç".

Kısacası, evlilikle birlikte kadınlardan kadınlık rollerini, erkeklerden ise erkeklik rollerini gerçekleştirmeleri beklenmiştir. Ancak evlilikler çocuk yaşta gerçekleştirildiği ve evlilik konusunda bir bilinçlilik hali oluşmadığı için bu rollerin gerçekleştirilmesinde zorluklar yaşanmıştır. Erken yaşta evlenmenin yanı sıra, bu zorlukları tetikleyen önemli bir faktör de aileyle birlikte yaşamak olmuş, bu yaşam içerisinde sosyo-kültürel yapının kabulleri geleneksel değerler, 
cinsiyete dayalı ayrım ve dini inançlar doğrultusunda eşle olan ilişkiler kısıtlı kalmış ve "ayıp" olarak algılanmıştır. $\mathrm{Bu}$ da eşler arasında geçimsizlik başta olmak üzere pek çok sorunu beraberinde getirmiştir.

\section{Erken Evliliklerde Şiddet}

Şiddet, daha önce de belirtildiği üzere erken evliliklerin önemli sonuçlarından biri olmaktadır. Araştırmaya katılan kadın katılımcıların tamamı şiddete maruz kaldıklarını dile getirmişlerdir. Kadın katılımcıların biri sadece sözlü şiddette uğradığını ifade ederken yedisi hem sözlü hem de fiziksel şiddete maruz kaldıklarını belirtmişlerdir. Kadın katılımcıların şiddet üzerine görüşme yapılırken seslerinin titrediği görülmüş ve kimi zaman ağladıkları için görüşmeye ara verilmiştir. Bu yüzden şiddet olaylarının kadın katılımcılar üzerinde travmatik bir etki bıraktığı söylenebilir. Eşlerinin kadın katılımcılara uyguladıkları şiddetin nedenleri ise kıskançlık, aldatma ya da geçimsizlik olurken bir kadın katılımcının eşinin kendisine sebepsiz olarak şiddet uyguladığ görülmüştür.

K2: "Uyguladl. Fiziksel şiddet uyguladl. Ben ona uygulayamam ki gücüm yetmez ona. Şiddetin sebebi çocuklardl, aldatmaydı o şekil. Beni aldattı̆̆ını görünce tartıştım o da kendini haklı çıkarmak için bana şiddet uyguladı".

K5: "Evet karşıllklı oldu. Eşimin kafasında ütü kırdım. Önce ondan geldi şiddet, o bana vurunca ben de ona vurdum. Evlendikten hemen sonra şiddeti başladl. Illk bana bir yumruk attı, ben kalp krizi geçirmişstim ve o zamanlar hamileydim. Kıskançlıktan dolayı oldu şiddet”.

K7: "Eşimden sürekli şiddet gördüm dersem yalan olur ama saçma sapan şiddet gördüğ̈̈mü anlatayım kendi bulunduğu iş yerinde arkadaşları ona işte takılmış. Isşte sen kilıbık birine mi benziyorsun? Daha yeni başladı̆̆ bir iş yeriydi. Aslında şakalaşmışlar. O da demiş ki kılıbık değilim, gider döverim. Neyse işte akşam eve geldi. Bulaşık yılkyordum. Kapıyı açtım. Tekme tokat girişti ve neye uğradiğımı şaşırdım. İste sonra da iş yerinde gidin bakın nasıl dövdüm demiş ve iş yerindeki arkadaşları geldi. Hepsi benden özür diledi, hepsi helallik istedi. Işste böyle bir şey yapacaklarını tahmin etmemişler falan, işte böyle saçma sapan yerlerde şiddetini görmüşümdür”.

$\mathrm{Bu}$ ifadelerden anlaşılacağı üzere şiddet, kimi zaman erkeklik göstergesi, kimi zaman ise anlaşmazlıkların ifadesidir. Şiddet, güç bakımından erkeklerle özdeşleştirilmiş olup bazı katılımcılar tarafından karşılıklı uygulanmıştır. Erkek katılımcıların evliliklerinde şiddet olgusu ve şiddete yönelik düşüncelerine bakıldığında ise erkek katılımcıların tamamının eşlerine sözlü veya fiziksel şiddet uyguladıkları görülmüştür. Sadece dört erkek katılımcıda sözlü veya fiziksel şiddet karşılıklı bir hal almıştır. Şiddet, bir katılımeı tarafından "okşama" olarak ifade edilmiştir. $\mathrm{Bu}$ ise şiddetle ilgili farkındalığın olduğunu ve çevreye karşı bunun yumuşatılarak belirtildiğini göstermektedir. Şiddet, kadınlarda olduğu gibi erkeklerde de erkeğin gücü ile özdeşleştirilmiş ve şiddet uygulama hakkı erkekte görülmüştür. Böylelikle kadının şiddet uygulayamayacağ belirtilmiştir. Buradan, şiddet denildiğinde fiziksel şiddetin anlaşıldığ 1 sonucuna varılabilmektedir. Sözlü şiddetten ziyade dövme, tokat atma gibi eylemleri içeren fiziksel şiddete değinilmiştir. Şiddetin nedenleri ise cahillik, çocukluk/gençlik, geçimsizlik, kıskançlık, erkekliğin ispat edilme çabası olarak belirtilmiştir.

E1: "Vallahi eskiden şiddet vardl. Hafif okşamam oldu. Yani mutlaka oldu. Eskiden cahiliye dönemindeydim şiddet uyguladım. Eşim bana 
şiddet uygulayamaz. Kadın güç konusunda erkekle mücadele edemez. Cahillikten kaynaklı şiddet uyguladım. Ama bir erkeğin kadına vurması kadar adice bir şey olamaz. Ben o hareketlerimi bile hatırlamak istemiyorum. Yani bir kadının sana gücü yetmiyor ama sen kalkıp onu dövüyorsun. Ben o hareketlerimi bile hatırlamak istemiyorum. Yaklaşık 13 yıl geçti ama ben çok pişmanım".

E5: "Eşime şiddet çok uyguladım. İlk eşime uyguladım. Hatta ilk eşimle tokatlaşmıştık. $O$ bana tokat atmıştı, ben de ona. Ama ikinci evliliğimde de eşime birkaç tokat atmışımdır. Çünkü 2. eşim beni değil annesini dinliyordu. Benimle zıtlaşıyordu. Illk eşimde de ben çok kiskançlık yapıyordum, o yüzden ona tokat atmiştım".

E8: "Çok bağırdım, çok kızdım ama hiçbir zaman dövmedim. Ben dövmeye karşıyım. Eşim de bana şiddet uygulamadı. Ama birbirimize çok bağırdık çok tartıştık”.

Kısacası, erken evliliklerle birlikte çocuk yaşta olunması, cahillik, gençliğin yaşanamaması, erkekliğin ispat edilme çabası, kıskançlık, aldatma ve geçimsizlik gibi nedenler aile içi şiddeti doğurabilmektedir. Burada kadınlar daha çok erkeklerden gördükleri şiddetin mağduru olabildikleri gibi şiddet esnasında kendileri de şiddete şiddetle cevap verebilmişlerdir. Ancak temel olarak katılımcılar şiddet denildiğinde sözlü şiddetten ziyade fiziksel şiddeti algılamışlar ve ekonomik, psikolojik vb. şiddet türlerine değinmemişlerdir.

\section{Erken Evliliklerde Boșanma}

Tablo-1 ve Tablo-2'de belirtildiği üzere, araştırmada yer alan erkek katılımcıların biri ve kadın katılımcıların ikisi boşanmışlardır. Erkek katılımcıların altısı boşanmaya karşı olduklarını ifade etmişlerdir. İkisi ise boşanmaya 1lımlı yaklaşmışlardır. Erkeklerin boşanmayla ilgili vurgularında temel faktör, "namus" olmaktadır. Buna göre, boşanmanın ardından eşlerinin başka bir erkekle herhangi bir ilişki içerisinde olması onlar açısından kendi namuslarına yönelik bir tehdit olarak değerlendirilmektedir. Burada aldatma da temel bir faktör olmakta ve bir boşanma nedeni olarak görülmektedir. Namus ve aldatmanın dişında boşanmaya dini gerekçeler ve çevre etkisiyle de karşı çıkılmaktadır. Erkek katılımcılar içerisinde boşanmaya 1lımlı bakanlarda bile namus vurgusu dikkat çekmektedir. Boşanma, ölüm ile eş değer görülmektedir.

E1: “...Boşanma konusu bana ters. Bir insan boşantyor, eşi de gidip başkastyla evlenecek bu fitrata ters. Ama bazı durumlar kabul edilebilir de ben kabul edemem. Ha şöyle olabilirdi anca, belki ilk nişanlandiğımızda bir şeyler yapılabilirdi. Ama söz kesildi, nişan takıldı. O saatten sonra 'Benim namusumdur.' dedim ve kabul ettim. Ben mesela kaç defa niyet ettim vazgeçmek için. Ama sonra düşündüm taşındım filan. Bana akl verenler oldu. 'Sonuçta bu senin karın olmuş.' dediler, 'Senin eşinin başka biriyle gitmesine nasll razı olursun?' falan dediler. Ben de tabii kabul edemedim bu durumu, dedim benim kabulümdür. Ailem de benim gibi düşünür. Boşanmaya karşıdırlar. Çünkü boşanmak ölüm demektir".

E4: "Boşanmayı defalarca düşündüm. Ama ben kimseyi yarı yolda bırakmak istemedim. O yüzden karımdan ayrılmadım. Ama boşanmama imkanım vardl. Ben istemedim... Evinde huzursuzluk olan, eşini aldatmış, namusunu kirletmiş olan bir evlilik devam ettirilmemeli, boşanmalıdırlar. Ailem boşanma konusuna olumlu bakar. Özellikle benim evliliği- 
min bitmesini çok ister çünkü ona göre bizim evliliğimiz bir balinanın küçük bir balı̆̆ yutmasıyla aynı şeydir. (Eşinin kendisinden büyük olması nedeniyle böyle bir ifade kullanılmıştır.) Ben boşanmış olsaydım ailem çok sevinirdi”.

Kadınlarda ise erkeklerin tersine boşanmaya daha 1lımlı yaklaşılmıştır. Kadınların sadece biri boşanmaya karşı olduğunu belirtirken diğer yedi katılımcı boşanma konusunu olumlu değerlendirmişlerdir. Bu değerlendirmeler içerisinde temel olarak çocuk vurgusunun yapıldığı görülmektedir. Kadın katılımcılar, çocuk sahibi olmak ile evliliğin sürdürülmesi gerekliliğini özdeşleştirmişlerdir. Diğer yandan, boşanma ile birlikte ekonomik kaygıların da ortaya çıtı̆̆g görülmektedir. Özellikle ailelerinin boşanmaya karşı olması bu kaygılar üzerinde tetikleyici olmuştur. Böyle durumlar kadınlar açısından aldatılmanın bile kabullenilmesine sebebiyet vermiştir.

K3: "Hiç düşünmedim. Sonradan eşimi çok sevdim. Ama o ayrılmak istedi, ben ayrlmak istemedim. Hayır, imkan yoktu. İki aile de karşıydl. Daha sonra eşim boşanmay istedi. Dedi ki 'Ben Gürcistanlı bir bayanla beraberim. Evlenmem gerekiyor onunla. Bizim boşanmamız lazım. Sen boşanma davasını aç.' dedi. Ondan sonra ben boşanma davasını açtım. Daha sonra ailelere anlattım. Onlar da bu durumu kabullenince ben de boşanma davasını açtım... Boşanmaya karşıyım ama benim durumumda olanlar boşansin bence. Ailem karşıdır boşanmaya. Onlara göre doğru değil. Ama benim durumum zor bir durum olduğu için ses etmediler".

K8: "Düşündüm hem de defalarca. Ama çocuklarım vardl. Evlendiğim birkaç ay sonrasında hamile kaldım. Sanki Allah boşanmamı istemiyormuş gibi bize çocuk vermişti. Boşanmak istedim. Ama hem çocuklarım bana engel oldu hem de ailem buna izin vermedi. Boşanıp eve dönsem ailem bana ve çocuğuma bakmazdl, biz perişan olurduk işte... Bence boşanma konusunda eğer çiftlerden biri şiddet görüyorsa veya mutsuzsa boşanması gerekir. Ailem ... Zaten beni perişan eden onlardl. Onlar bana destek olsaydı şimdi çoktan boşanmıştım. Aileme göre boşanmak ölmek demektir. Onlara göre boşanan kadın namusunu koruyamaz. Ama işte çok yanlış biliyorlar. Bunlar hep ailemin cehaleti yüzünden geldi benim başıma".

Hem erkek katılımcıların hem de kadın katılımcıların düşünceleri doğrultusunda boşanma konusunda kültürel yapının belirleyici bir unsur olduğu görülmektedir. Buna göre boşanma, ölüm ile özdeşleştirilmektedir. Burada kastedilen özellikle boşanmış kadınlar açısından eşlerinden boşanma ile yeni bir hayat başlangıcı ya da yeni bir eş, yeni bir ilişki kurulamayacağı doğrultusundadır. Erkekler açısından ise boşanma, eşin yarı yolda bırakılmasıdır. Bu ise evliliğin ömür boyu sürdürülmesi gerektiğini göstermektedir. Boşanma sosyo-kültürel açıdan erkeklerin erkekliklerinin sorgulanmasıyla sonuçlanabilmektedir. Kadınlar boşanmaya erkeklere göre daha 11ımlı yaklaşmaktadırlar. Özellikle şiddet, aldatma gibi hususlar boşanmanın temel nedenleri olmaktadır. Ancak çocuk sahibi olmak onların boşanmalarını engellemektedir. Oysaki erkek katılımc1larda çocuk sahibi olmaktan ziyade namus düşüncesi daha baskın gelmektedir. Namus düşüncesiyle erkek katılımcılar eşlerinin namusunu kendi namusları olarak görmekte boşanma durumunda ise ataerkil aile yapısı, geleneksel değerler ve içinde bulunduğu yerin sosyo-kültürel etkisi ve çevre baskısı bu durumu olumsuz karşılamaktadır.

\section{Erken Evliliklere Yönelik Çözüm Önerileri}

Literatürde erken evliliklere yönelik çözüm önerileri; kız çocuğunun toplumsal değerinin kabul 
edilmesi, ebeveynlere çocuk yetiştirme hususunda eğitimler verilmesi, çocukların özellikle de kız çocuklarının eğitim seviyelerinin yükseltilmesi, erken evliliklere yönelik kamu spotlarının oluşturulması, erken evliliklere yönelik yasal yaptırımların uygulanması, devletin çeşitli kurumlarının çeşitli etkinlikler ile bu konuda halkı bilgilendirmeleri ve bilinçlendirmeleri (Yüksel \& Yüksel 2014, 21) olarak belirtilmektedir. Bu araştırmada ise katılımcılar, eğitimin arttırılarak insanların erken evliliklere yönelik bilinçlenmelerinin sağlanması, bakanlıkların önlemler alması, kurslar açılması ve seminerler verilmesi, özellikle kadınların ekonomik açıdan özgürlüklerini elde edebilmeleri, sığınma evlerinin artması, evlilik yaşının yükseltilmesi, kanunlarda erken evliliklere yönelik düzenlemeler yapılması ve gerekirse erken evliliklerin geçersiz sayılması gibi çözüm önerileri sunmuşlardır.

E4: "Bana bir Cumhurbaşkanllğı verseler, bayanların evlenme yaşını 23 yapardım. Erkeklerin 25-26 yapardım. Yaşadı̆̆ım zorluktan dolayı diyorum. Bence gerçekten caydirıcı bir yasanın olması ve bunun uygulanmasi gerekiyor".

E8: "Toplum bilinçlendirilmeli, eğitimle düzeltilmesi lazım. Bu durumun anne baba bilinçlendirilmesi lazım. Kızın ve erkeğin de okutulması lazım. Okuyan klz ve erkek üniversite bitince belli bir yaşa geliyor zaten. Ondan sonra evlenebilir. Evlilik yaşı da yükselmiş olur böylece".

K4: "Okuması lazım, bir meslek sahibi olması lazım. Devlet daha iyi uygulamalar yapması lazım. Devlet sığınma evlerini arttırması lazım”.

K6: "Seminerler vermeleri gerekiyor. Anne-babaya seminerler verin. Kadınlara iş imkânı sağlansın ki kadınlar bir şeylere mecbur bırakılmasinlar. Ekonomik güç verildin kadınlara".

K7: "Bence bunun sosyal olarak bakanlıklar tarafindan, ülke tarafindan bu konuda biraz daha büyük önlemlerin alınması gerekiyor. Yaptırımların biraz daha ă̆ır olması gerekiyor ve dediğim gibi çocuk istedi, kendileri istedi diye bir düşünce olmayacak. Yani anne, baba çocuğu komşuya göndermediği gibi 18 yaşına kadar her birey çocuktur göndermediğ $i$ gibi evliliği de istediği takdirde onay vermeyecek. Buna çok dikkat etmesi gerektiğini düşünüyorum”.

K8: "Bence tek çare yeni yasalar çıkarılması lazım. Yaşın yükseltilmesi için bir çare yok. Anne baba imzasılyla yapılan evlilikler geçersiz sayılsın”.

Erken evliliklere yönelik belirtilen çözüm önerilerinin aksine, bu konuda herhangi bir önleme gerek olmadığını belirten bir katılımcı da bulunmaktadır.

E3: "Erken evlilikte zorluklar oluyor ama pek de önemli bir sorun degildir bence önlem alınmasa da olur. Çünkü erken evlilikte zamanla seversin birbirini ve sorun olmaktan çıkar bu durum”.

Bu ifadede ise erken evliliğin zaman içerisinde sevgi ile sonuçlanması nedeniyle herhangi bir sorun yaşanmayacağı vurgusu görülmektedir.

\section{Değerlendirme ve Sonuç}

Erken yaşta yapılan evliliklerin nedenlerine bakıldığında sorunun ilk olarak sosyo-kültürel özelliklerden kaynaklandığı görülmektedir. Dolayısıyla erken evlilikleri anlayabilmek için o toplumun sosyo-kültürel özelliklerinin ele alınması gerekir.

Erken evliliklerde sosyo-kültürel yapının etkisini görmeyi amaçlayan bu çalışma, Ağrı ilinde 8 kadın, 8 erkek toplamda 16 katılımcı ile gerçekleştirilmiştir. Erken yaşta evliliklere 
daha çok kız çocukları maruz kaldığından konu ile ilgili çalışmalar ağırlıklı olarak kız çocukları üzerine yapılmıştır. Ancak bu çalışma ile hem erkek hem de kız çocukları uygulama alanı olarak seçilmiştir. Nitekim Ağrı ilinin sosyo-kültürel özellikleri de göz önünde bulundurularak erken yaşta evliliğe sadece kız çocukları maruz kalmamakta erkek çocukları da erken yaşta evlenebilmekte/evlendirilmektedir. Dolayısıyla çocuk yaşta evliliğin normal görüldüğü bu yapıda sadece kız çocukları değil erkek çocukları da olumsuz etkilenmektedir.

Araştırma kapsamında elde edilen veriler değerlendirildiğinde erken evlilik kavramı ile 18 yaşın altında yapılan evlilikler kastedilmektedir. Bu evliliklerde, sosyo-kültürel yapının belirleyici olduğu görülmüştür. Sosyo-kültürel yapıda hakim olan ataerkillik ve geleneksellik, erken evliliği meşrulaştıran önemli bir unsurdur. Konu ile ilgili yapılan çalışmalarda (Orçan \& Kar 2008; Burcu et al. 2015) da benzer sonuçlar görülmektedir. Yapılan çalışmalara göre erken evliliklerde geleneksellik ön plana çıkmakta, kadınlar içinde bulundukları yapının kültürel özellikleri doğrultusunda evliliğe itilmektedir. Bu evlilikler de "namus algısı" gibi söylemlerle meşrulaştırılmaktadır.

Ataerkil aile yapısı ve geleneksel değer yargıları ile kadınlar toplumda ikincilleştirilmekte ve namus kaygısı ile kadınların erken yaşlarda evlenmeleri ve çocuk sahibi olmaları beklenmektedir. Ancak çocuk yaşta hem ev içi rollerin üstlenilmesi hem de çocuk bakımında bilinçli olunmaması evliliklerde zorluklar yaşanmasına neden olmaktadır. Diğer yandan, çocuk yaşta çocuk sahibi olunması kadın açısından sağlık sorunlarına da yol açabilmektedir. Araştırmada elde ettiğimiz bu sonuçlara paralel şekilde Anık ve Barlin'in (2017) yaptığı çalışmada da erken evlilik yapan kız çocuklarının çocuk olmanın yanında eş ve annelik rolünü üstlendikleri ifade edilmektedir. Çalışmamız erkekler açısından ele alındığında ise ataerkil yapı erkeklere ayrı bir güç atfetmektedir. Buna göre, erkeklerin bir işte çalışacak ve evin geçimini sağlayacak güçte olmaları evlilik gerçekleştirmeleri için yeterli görülmektedir. Ancak, erkekler açısından bu süreçte yaşanan zorluk, askerlik yapılmadan evlenilmiş olmasıdır. Askerlikten önce gerçekleşen evliliklerde, askerlik dönemi içerisinde her iki eş açısından da maddi-manevi zorluklar yaşanmaktadır.

Sosyo-kültürel yapı içerisinde ataerkil yapıya bağlı olarak eğitimsizlik de erken evliliklerin hem bir nedeni hem de bir sonucudur. Buna göre, toplumsal açıdan hem kız hem de erkek çocuklarının eğitimine önem verilmemektedir. Burada ebeveynlerinin eğitim durumlarına da dikkat etmek gerekmektedir. Araştırmada yer alan katılımcıların ebeveynlerinin eğitim durumlarının düşük olduğu görülmektedir.

Yüksel-Kaptanoğlu ve Ergöçmen (2012) çalışmasında ailelerin yasal olarak evlenmeye hazır olmayan kız çocuklarını evlendirirken dini nikâha başvurdukları ifade edilmektedir. Toplumda kabul görülen bu durum kız çocuklarının istismara, şiddete ve baskıya maruz kalmalarına neden olabilmektedir. Yüksel-Kaptanoğlu ve Ergöçmen'in yaptıkları çalışmada elde ettikleri sonuçlar araştırmamızı destekler niteliktedir. Araştırmamızda ebeveynlerin ve sosyal çevrenin düşünceleri üzerinde etkili olan gelenekler-görenekler, dini inançlar ya da söylemler de erken evlilikleri tetikleyici niteliktedir. Din açısından erken evlilikler kadere bağlanarak açıklanmakta ve meşrulaştırılmaktadır. Dini nikâha önem verilmesi de erken evlilikleri arttırıcı niteliktedir. Ancak dini nikâh ile gerçekleşen evliliklerde özellikle de çocuk sahibi olduktan sonra kamu işlemlerinin gerçekleştirilmesinde sorunlar yaşanmaktadır. Toplumsal açıdan ise 18 yaşın altında evlenilmesi erken evlilik olarak betimlenmemektedir. $\mathrm{Bu}$ da içinde bulunulan sosyo-kültürel yapıya bağlı olarak erken evlilikleri sıradanlaştırılıp normalleştiren ve bunu meşru gösteren bir eylem haline getirmektedir.

Erken evlilikler, sosyo-kültürel yapının meşrulaştırıcı etkisiyle gerçekleşse de bir takım olumsuz sonuçlara yol açmaktadır. Bunlardan biri, çocuk istismarıdır. Erken evlilikler 
çocukların gerek cinsel açıdan gerek ekonomik (iş gücü) açıdan gerekse de psikolojik açıdan sömürülmelerine neden olmaktadır. Çocuklar, çocukluklarını yaşayamadan kendilerini eşe, eşin ailesine, çevreye karşı sorumluluklar ve beklentiler içerisinde bulmaktadır. Diğer yandan, çocuk sahibi olmakla birlikte ebeveynlik rol ve sorumluluklarını da üstlenmektedir. $\mathrm{Bu}$ durum, bireylerin aynı zamanda eğitimlerini yarıda bırakmalarına neden olmaktadır.

Erken evliliklerin önemli bir sonucu da şiddettir. Özellikle görücü usulü, berdel gibi geleneksel uygulamalarla gerçekleşen erken evliliklerin şiddetle sonuçlandığı görülmüştür. Şiddet, erkekliğin bir kanıtı olarak nedensiz yere olabildiği gibi eşlerin anlaşamaması, ailenin ekonomik durumu, geniş aile yapısı gibi nedenlerle de gerçekleştirilebilmektedir. Bu da boşanma konusunu akla getirmektedir. Araştırmada, sosyo-kültürel açıdan boşanmaya "namus" düşüncesiyle 1lımlı yaklaşılmadığı görülmüştür.

Özetle, erken evlilikler toplumun kültürel değerlerinde varlığını ve önemini korumaktadır. İçinde bulunulan sosyo-kültürel yapıya bağlı olarak ataerkil aile yapısı, kültürel değerler, geleneksel uygulamalar ve dini ritüeller gibi birçok etken erken evliliği meşru bir zemine oturtmaktadır. Dolayısıyla konu ile ilgili olarak yasal yaptırımların olmasına, özellikle kız çocuklarının eğitim seviyelerinin yükseltilmesine, ailelerin bu konuda bilinçlendirilmesine, kısacası bir zihniyet değişikliğine ihtiyaç duyulmaktadır.

\section{KAYNAKÇA}

Anık M. \& Barlin R. (2017). "Türkiye'de Çocuk Gelinler Sorunu: Balıkesir Örneği”. İnsan ve Toplum Bilimleri Araştırmaları Dergisi 6/3 (2017) 1827-1841.

Aydemir E. (2011). "Evlilik Mi Evcilik Mi? Erken ve Zorla Evlilikler Çocuk Gelinler”. Uluslararası Stratejik Araştırmalar Kurumu Sosyal Araştırmalar Merkezi, USAK Rapor No: 11.

Aydın D. \& Akay B. (2017). "Hemşirelik Öğrencilerinin Erken Evlilik ve Çocuk Gelinler Hakkındaki Görüşlerinin Belirlenmesi”. Clinical and Experimental Health Sciences 7 (2017) 39-44.

Bates L. M., Joanna M. \& Sidney R. S. (2007). "Women's Education and the Timing of Marriage in the Next Generation: Evidence From Rural Bangladesh”. Studies in Family Planning 38/2 (2007) 101-112.

Bindik S. (2012). Sosyolojik Açıdan Kadınlarda Erken Yaşta Evlilik (Nevşehir İli Derinkuyu İlçesi Örneği. Yayımlanmamış Yüksek Lisans Tezi. Nevşehir Üniversitesi, Nevşehir 2012.

Birleşmiş Milletler (1989). Birleşmiş Milletler Çocuk Haklarına Dair Sözleşmesi.

Kaynak: http://cocukhaklari.barobirlik.org.tr/dokuman/mevzuat_uamevzuat/birlesmismilletler.pdf

Boran P., Gülçay G., Devecioğlu E. \& Eren T. (2013). “Çocuk Gelinler”. Marmara Medical Journal 26 (2013) 58-62.

Burcu E., Yıldırım F., Sırma Ç. S. \& Sanıyaman S. (2015). "Çiçeklerin Kaderi: Türkiye'de Kadınların Erken Evliliği Üzerine Nitel Bir Araştırma”. Bilig 73 (2015) 63-98.

Burcu-Sağlam E. (2018). “Araştırma Yöntem ve Teknikleri”. Eds. E. Burcu-Sağlam, A. ÖğünBoyacıoğlu \& A. Gelgeç-Bakacak, Sosyoloji (2018) 99-136. Ankara.

Çocuk Koruma Kanunu. (2005). Türkiye Cumhuriyeti, 5395 (9501-9514-1). Kaynak: http://www. mevzuat.gov.tr/MevzuatMetin/1.5.5395.pdf

Erdoğan D. (n. d.). Türkiye'de Çocuk Gelinler Sorunu. Kaynak: http://www.academia.edu/6459715/ Turkiyede_Cocuk_Gelinler_Sorunu

Gezer-Tuğrul Y. (2018). "Erken Yaşta Evlendirilen Kadınların Evlilik Süreçleri, Deneyimleri ve Sonraki Yaşamları Üzerine Nitel Bir Çalışma”. Sosyoloji Notları 2 (2018) 2-38.

Hervish A. \& Feldman-Jacobs, C. (2011). Who Speaks for Me. Population Reference Bureau Policy Brief.

le Strat Y., Dubertret C. \& le Foll B. (2011). "Child Marriage in the United States and Its Association with Mental Health in Women”. Pediatrics 128/3 (2011) 524-530.

Moss J. J. (1965). "Teenage Marriage: Crossnational Trends and Sociological Factors in the Decion of When to Marry”. Acta Sociologica 8/1-2 (1965) 98-117. 
Source: https://journals.sagepub.com/doi/pdf/10.1177/000169936500800109

Orçan M. \& Kar M. (2008). “Türkiye’de Erken Yaşta Yapıllan Evlilikler ve Risk Algısı: Bismil Örneği”. Sosyal Politika Çalışmaları Dergisi 14/14 (2008) 97-111.

Ova N. (2014). “Türkiye’de Yazılı Basında 'Çocuk Gelinler'in Temsili”. Selçuk Üniversitesi İletişim Fakültesi Akademik Dergisi 8/2 (2014) 238-262.

Özcebe H. \& Biçer B. K. (2013). “Önemli Bir Kız Çocuk Ve Kadın Sorunu: Çocuk Evlilikler”. Türk Pediatri Arşivi Dergisi 48 (2013) 86-93.

Raj A. \& Boehmer U. (2013). “Girl Child Marriage and Its Association with National Rates of HIV, Maternal Health, and Infant Mortality Across 97 Countries”. Violence Against Women 19 (2013) 536-551.

Raj A., Gomez C. S. \& Silverman J. G. (2011). "Multisectoral Afghan Perspectives on Girl Child Marriage: Foundations for Change Do Exist in Afghanistan”. Violence Against Women 20/10 (2011) 1-17.

Şen H. (2014). "Çocuk Evliliklere Teoriden Bakmak”. Ed. H. Şen, Çocuk Gelinler: Evcilikten Evliliğe (2014) 25-44. Ankara.

Tan-Eren G. (2017). Erken Evliliği Deneyimleyen Kadınların Evliliğe İlişkin Düşüncelerinin SosyoKültürel Temeli: Ardahan Örneği. Yayımlanmamış Yüksek Lisans Tezi. Hacettepe Üniversitesi, Ankara 2017.

TBMM. (2010). Erken Yaşta Evlilikler Hakkında İnceleme Yapılmasına Dair Rapor. Kaynak: https://www.tbmm.gov.tr/komisyon/kefe/docs/komisyon_rapor.pdf

Türk Ceza Kanunu. (2004). Türkiye Cumhuriyeti, Türk Ceza Kanunu. 5237. Kaynak: https://www.tbmm. gov.tr/kanunlar/k5237.html

Türk Medeni Kanunu. (2001). Türkiye Cumhuriyeti, Türk Medeni Kanunu. 4721 (8049-8210). Kaynak: http://www.mevzuat.gov.tr/MevzuatMetin/1.5.4721.pdf

United Nations Children’s Fund (UNICEF). (2001). Early Marriage: Child Spouses. Florence 2001.

United Nations Children's Fund (UNICEF). (2005). Early Marriage A Harmful Traditional Practice: A Statistical Exploration. New York 2005.

Source: http://www.unicef.org/publications/files/Early_Marriage_12.lo.pdf

United Nations Children's Fund (UNICEF). (2005). Early Marriage: Child Spouses. Florence 2005.

United Nations Children's Fund (UNICEF). (2006). Child Protection Information Sheets. Source: http://www.unicef.org/protection/files/Child_Marriage.pdf

United Nations Children's Fund (UNICEF). (2014). The State of the Worlds Children 2014: Every Child Counts. New York 2014.

United Nations Population Found (UNFPA). (2012). Marrying Too Young: End Child Marriage. New York 2012.

Yüksel H. \& Yüksel M. (2014). "Çocuk İhmali ve İstismarı Bağlamında Türkiye'de Çocuk Gelinler Gerçeği”. Çankırı Karatekin Üniversitesi Sosyal Bilimler Enstitüsü Dergisi 5/2 (2014) 1-24.

Yüksel-Kaptanoğlu İ. \& Ergöçmen B. A. (2012). “Çocuk Gelin Olmaya Giden Yol”. Sosyoloji Araştırmalarl Dergisi 15/2 (2012) 128-161. 